Betha Lusiana, Lisa Tanika, Sacha Amaruzaman, Beria Leimona 



\section{Potential and challenges in developing co-investment for ecosystem services schemes in Buol district, Indonesia}

Betha Lusiana, Lisa Tanika, Sacha Amaruzaman, Beria Leimona 


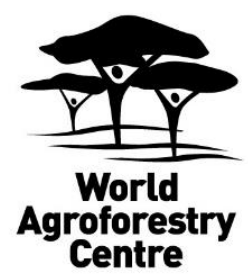

Citation: Lusiana B, Tanika L, Amaruzaman S, Leimona B. 2015. Potential and challenges in developing payment for ecosystem services scheme in Buol District, Indonesia. Working Paper 211. Bogor, Indonesia: World Agroforestry Centre (ICRAF) Southeast Asia Regional Program. DOI: http://dx.doi.org/10.5716/WP15722. PDF

Titles in the Working Paper Series aim to disseminate interim results on agroforestry research and practices and stimulate feedback from the scientific community. Other publication series from the World Agroforestry Centre include: agroforestry perspectives, technical manuals and occasional papers.

Published by the World Agroforestry Centre (ICRAF)

Southeast Asia Regional Program

PO Box 161, Bogor 16001

Indonesia

Tel: +62 2518625415

Fax: +622518625416

Email: icraf-indonesia@cgiar.org

Website: http://www.worldagroforestry.org/region/southeast-asia

(C) World Agroforestry Centre 2015

Working Paper no. 211

\section{Disclaimer and copyright}

The views expressed in this publication are those of the author(s) and not necessarily those of the World Agroforestry Centre. Articles appearing in this publication may be quoted or reproduced without charge, provided the source is acknowledged. All images remain the sole property of their source and may not be used for any purpose without written permission of the source. 


\section{About the authors}

Betha Lusiana, $\mathrm{PhD}$ is a scientist with the World Agroforestry Centre (ICRAF) Indonesia programme, where she leads the Ecological Modelling Unit. She also coordinates the Smart TreeInvest project activities in Indonesia. She has a $\mathrm{PhD}$ from Hohenheim University, Germany, where her dissertation focused on the use of land-use change models for natural research management. Her current research focuses on assessing the trade-offs between agricultural development, farmers' livelihoods, and ecosystem services through the use of participatory, quantitative and/or model simulation approaches. In particular, she is interested in exploring and analysing the use of such assessments for natural resource management.

Lisa Tanika joined ICRAF in 2008 as an ecological modeller. Lisa has a background in Mathematics (BSc) and Applied Climatology (MSc) from Bogor Agriculture University. Her research focuses on the use of the Generic River Flow (GenRiver) Model to assess watershed functions, in particular to explore the effect of land cover change and climate change on the overall hydrological functions of a watershed. She is also interested in developing and applying participatory approaches for local stakeholders to monitor watershed functions.

Sacha Amaruzaman is an ecosystem services specialist with the World Agroforestry Centre Southeast Asia. He co-manages the Climate-Smart Tree-Based Adaptation and Mitigation in Asia (Smart Tree-Invest) project that is operating in Indonesia, Vietnam and the Philippines. He also carries out research under the CGIAR Research Program on Forest, Trees and Agroforestry, focusing mainly on the socioeconomic and institutional aspects of ecosystem services. He obtained his master degree from Wageningen University, the Netherlands, majoring in Environmental Science.

Beria Leimona, $\mathrm{PhD}$ is an ecosystem service governance and institution specialist with over fifteen years of experience in policy analysis, behavioural experiments, programme development and implementation, and institutional capacity strengthening. She contributes in designing and analysing pro-poor payment for ecosystem services initiatives in Asia in collaboration with stakeholders from different backgrounds. She is one of the resource persons for the Indonesian Ministry of Environment and Forestry on the policies related to ecosystem services and environmental economic incentives. At the global level, Leimona is a member of the Executive Steering Committee of the Ecosystem Service Partnership Network, a senior member of the Environment and Economics Partnership for Southeast Asia and Indonesia network, a lead author for the Intergovernmental Platform for Biodiversity and Ecosystem Services (IPBES), and an Associate Editor for the Ecosystem Services Journal of Elsevier. At the moment, she is coordinating the Southeast Asia regional branch of the Smart Tree-Invest project in Vietnam, Indonesia, and the Philippines. 


\section{Abstract}

Developing a co-investment scheme to enhance the provision of ecosystem services (ES) and farmers' livelihoods requires a comprehensive understanding on the condition of ES and how farmers interact with and use the natural resources in the landscape. This paper describes the result of the initial phase in developing a co-investment scheme in Buol district, Central Sulawesi, Indonesia. The coinvestment of ES schemes aims to support the local farmers and government in managing their landscape sustainably while also improving farmers' livelihoods.

Using the Capacity Strengthening for Vulnerability Assessment (CaSAVA) framework, we assess the environmental and socio-economic issues faced by both farmers and the local governments, which influence their vulnerability and provide challenges to the implementation of a co-investment for ES scheme. Buol landscapes represent a typical forest frontier area where forest is being converted into more intensive systems of oil palm plantation and massive smallholder maize systems. The geographic location of the district along the coastal line of the Sulawesi Sea offers diverse livelihood options for farmers but also poses many environmental challenges.

The socio-economic problems faced by farmers are related to agricultural pests and diseases, scarcity of farm inputs in the market, and limited access to sell products on the market. The environmental issues faced by farmers and local governments are related to coastal abrasion and river-bank collapse along the Buol river, the area's main river whose catchment takes up a third of the entire district. The lack of market access and the only recently developed roads have prevented the development of industrial or private companies; hence the lack of ES buyers in the area. Therefore, co-investment schemes involving public funding are deemed the most feasible for Buol district.

The co-investment activities in the form of climate-smart agriculture that can maintain and rehabilitate ecosystem service provisioning in the landscape.

Observing the local conditions, we understand that improving farmer and local government awareness of ecosystem services, and enhancing their ability to monitor the quality and quantity of ecosystem services in their area are prerequisites to develop sustainable co-investment schemes. The challenges that lie in the low awareness and capacity of local stakeholders can be overcome through trainings and awareness campaigns aimed at those actors. However, the main challenge lies in the willingness and commitment of both parties to work together sustainably, which requires a process of learning together and negotiation. It is essential that 'honest' brokers exist, with the ability and capacity to facilitate and mediate the process.

\section{Keywords}

Ecosystem services, co-investment, participatory and inclusive approach, Central Sulawesi, SWOT analysis 


\section{Acknowledgements}

This study is funded by International Fund for Agricultural Development (IFAD) through the Climate-Smart, Tree-Based, Co-Investment in Adaptation and Mitigation in Asia project (Smart TreeInvest). We would like to acknowledge the Smart Tree-Invest team who helped in collecting data in the field: Atiek Widayati, Adhitya Wirayasa, Adis Hendriatna, Arief Prasetyo, Chandra Wijaya, Dienda Cietyasari Hendrawan, Dinna Tazkiana, Hartiningsih, and Subekti Rahayu. We also appreciate the logistical support from Ibu Sarwani during data collection. We are particularly thankful to the communities of Kokobuka, Lomuli, Air Terang, Boilan, Balau, Taat, Matinan, and Lokodidi who have participated in our activities and enthusiastically shared with us their views and life experiences. We gratefully acknowledge the support from BAPPEDA Kabupaten Buol. 


\section{Contents}

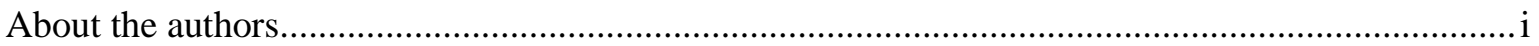

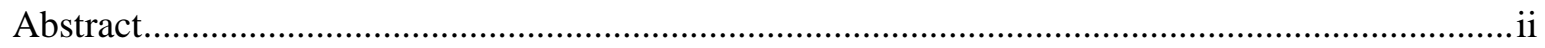

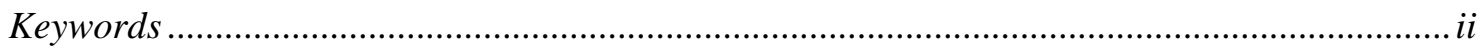

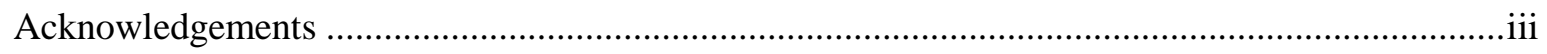

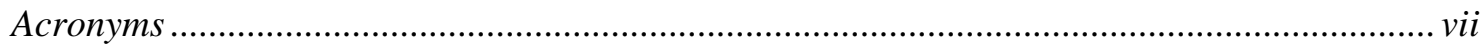

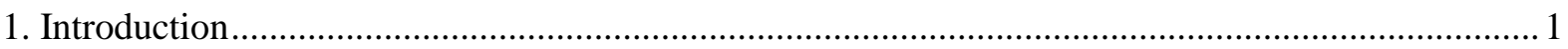

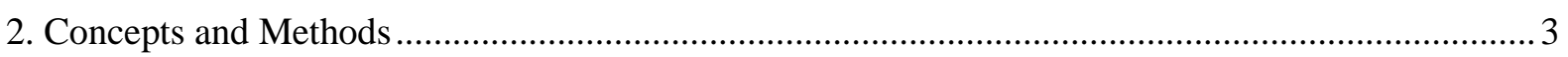

2.1 From payment to co-investment of ecosystem services ........................................................... 3

2.2 Assessing the potential of PES schemes in Buol landscape ..................................................... 4

2.2.1 Assessing the provisioning of ecosystem services........................................................... 5

2.2.2 Key informant interviews and focus group discussion at district level ............................... 6

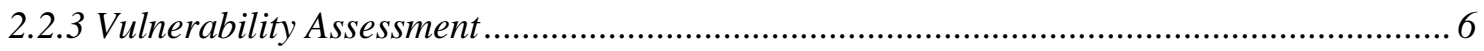

2.2.4 Strength, Weakness, Opportunity and Threat (SWOT) analysis....................................... 7

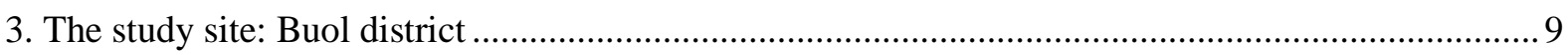

3.1 Geographic location, general socio-economic and environmental condition ............................. 9

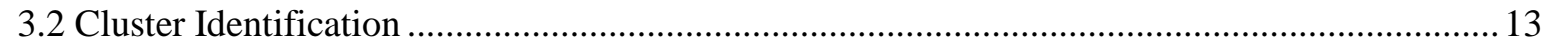

4. Results 15

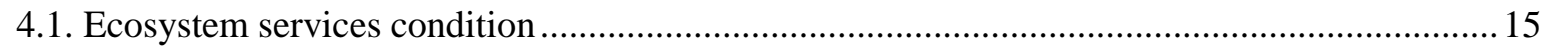

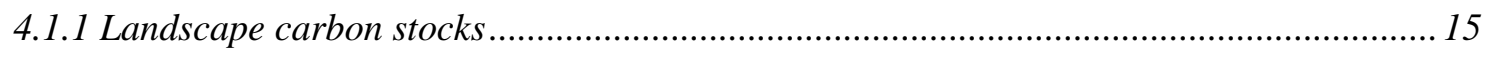

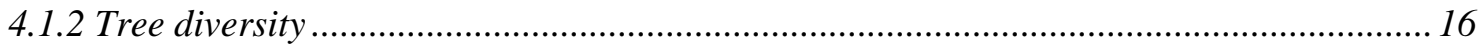

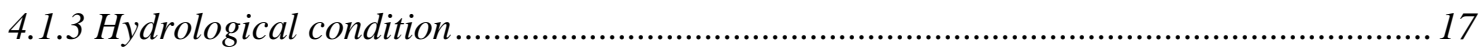

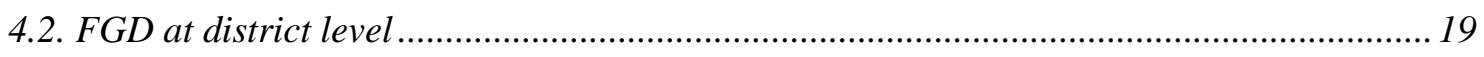

4.3 Vulnerability assessment: Shock, Exposure, Response and Impact .................................... 20

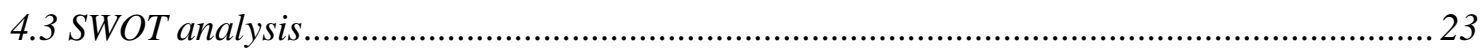

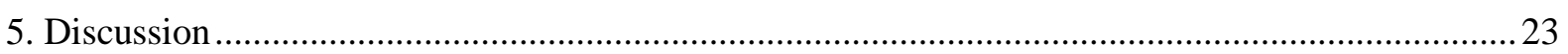

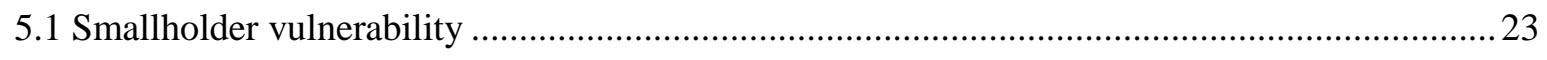

5.2 Challenges in developing co-investment schemes................................................................ 24

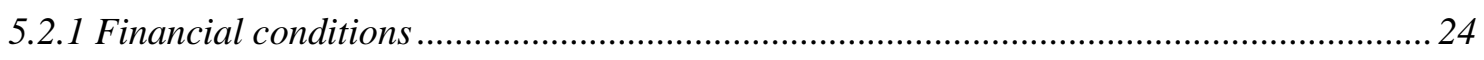

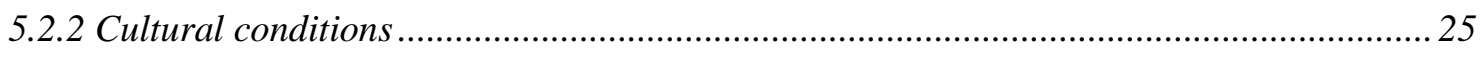

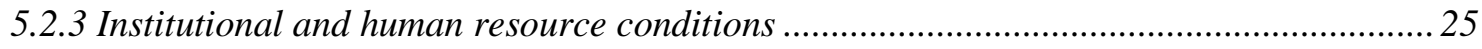




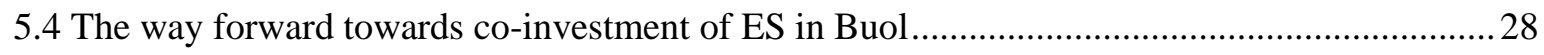

5.4.1 Establishment of a local multi-stakeholder forum as the intermediary ............................ 28

5.4.2 Building the capacity of local stakeholders to support co-investment schemes ................. 28

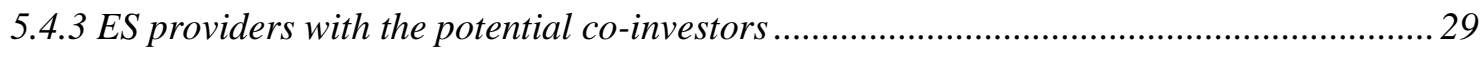

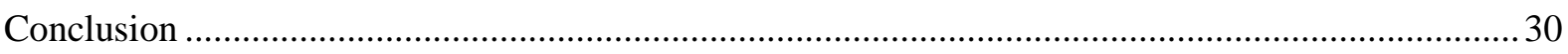

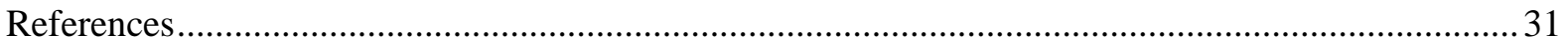

Appendix 33

\section{List of tables}

Table 1. Land use/cover types and its carbon stock used in Buol District.

Table 2. Number of participants from local government at sub-district and village levels, and number of village representatives in each cluster

Table 3. Number of farmers participating in the FGD for vulnerability assessment in each actionresearch site in Buol

Table 4. General characteristics of the action-research sites of the Smart Tree-Invest project in Buol district.

Table 5. Carbon sequestration, carbon emission, and net $\mathrm{CO}_{2}$-emissions in Buol district for the period 1996-2014

Table 6. Similarity of the tree species across land-use systems using Bray-Curtis Index.

Table 7. Rank of hydrological problems in each action-research site cluster, differentiated by gender, with 1 being most problematic and the first priority to be solved. Symbol $\sqrt{ }$ means that the issue is considered problematic but of lower priority.

Table 8. The main issues in coastal and watershed areas.

Table 9. The natural disasters experienced by the communities, the impact on the community, and community responses.

Table 10. The extreme events experienced by communities, impact on the community, and community responses.

Table 11. The shocks, exposure and buffers in the upland and coastal communities of Buol.

Table 12. Ecosystem services provisioning and their associated providers' and beneficiaries' potential for RES scheme development in Buol district. 


\section{List of figures}

Figure 1. The framework of the current study, based on the cascade model of ecosystem services (modified from Braat and de Groot, 2008).

Figure 2. Capacity Strengthening Approach to Vulnerability Assessment (CaSAVA) framework. Source: Dewi et al (2013)

Figure 3. Location of Buol district within Central Sulawesi and the three action-research sites where this study was carried out.

Figure 4. The Buol watershed with the location of the rainfall and river discharge station.

Figure 5. The average monthly rainfall and monthly discharge in Buol, measured in the Buol watershed.

Figure 6. Distribution of land use/cover types in Buol district from 1996-2014 (A) and the associated distribution of carbon stocks (B). The reference point for the landscape carbon stocks is 1996.

Figure 7. Shannon-Wiener Diversity Index of seedling, sapling, pole, and tree in the various land-use systems in Buol...

Figure 8. Water sources for different uses in each action-research site under normal conditions and in the drought season. 


\section{Acronyms}

CaSAVA Capacity Strengthening Approach to Vulnerability Assessment

ES Ecosystem Service

FGD Focus Group Discussion

GERHAN Gerakan National Rehabilitasi Lahan dan Hutan (The National programme to Rehabilitate Land and Forest)

PAMSIMAS Program Air Minum dan Sanitasi Berbasis Masyarakat (Community Water and Sanitation Programme)

PES Payment for Ecosystem Services

PNPM Program Nasional Pemberdayaan Masyarakat (National Programme for Community Empowerment)

SWOT Strength, Weakness, Opportunity and Threat 



\section{Introduction}

Representing $85 \%$ of the world's farms and contributing at least $70 \%$ of world's food (Harvey et al 2014), smallholder farmers constitute a significant portion of the world's population. Ironically, smallholder farmers are also estimated to represent half of the hungry people worldwide (Sanchez and Swaminathan 2005). Across the tropics, smallholder farmers already face numerous risks to their agricultural production such as droughts and floods, crop and animal disease, and market shocks, which often undermine their household food and income security. Further exposure to climate-change risks will further increase the vulnerability of these smallholder farmers as they have limited resources and hence weak adaptive capacity.

In the past, most programmes aimed at increasing the world's food production focused on intensifying agricultural production through the use of chemicals, new crop varieties, and new technologies. However, such approaches may have negative consequences for the environment and raises the question of both economic and environmental sustainability, including the impact of such inputs on the quality of livelihoods. For example, high doses of fertilizers and pesticides can increase nutrients and toxins in ground and surface waters, incurring water purification and health costs (Tilman et al 2002), while the establishment of large-scale and intensive bio-fuel plantations has led to biodiversity loss (Danielsen et al 2009). Improved farming practices, in particular farming practices that involved planting trees such as agroforestry systems, can increase the sustainability of farming systems and contribute to reducing farmers' vulnerability to climate variability (Verchot et al 2007). Trees are critical resources to sustain smallholder livelihoods, as they not only provide an income for the households, but also maintain soil fertility, help control erosion, provide fuelwood or charcoal for cooking and lighting, supply construction materials and medicine, and act as a source of various food products (fruits, leaves and insects). Moreover, trees sequester carbon and thus play a crucial role in mitigating climate change due to carbon emission (Albrecht and Kandji 2003).

The Climate-Smart, Tree-Based, Co-Investment in Adaptation and Mitigation in Asia project (Smart Tree-Invest) funded by IFAD aims to develop a co-investment of ecosystem services scheme as a way of enhancing the provision of ecosystem services by promoting climate-smart agriculture in Indonesia, the Philippines, and Vietnam. The co-investment of ecosystem services scheme derives from the Payments for Ecosystem Services (PES) concept, where the PES scheme's market-like transaction principle is replaced by co-investment principles in which all actors can contribute, financially and non-financially, to the provision of ecosystem services (ES).

Developing a sustainable payment/co-investment for ecosystem services scheme requires a comprehensive understanding of the environmental and socio-economic challenges faced by farmers including the potential ecosystem services the landscape provides. Waage et al (2008) proposed a four-step method to develop a PES scheme: (i) identifying ecosystem service prospects as well as potential ES providers and buyers; (ii) assessing institutional and technical capacity of providers and buyers as well as scheme developers; (iii) designing appropriate agreements; and (iv) implementation of PES, including monitoring. Each step is important in ensuring the suitability and sustainability of 
the PES scheme. The first and second steps are the scoping stage, in which the ecosystem services condition and values, actors involved in the provision of and benefits from the services, and policy and institutional aspects that potentially influence the schemes are thoroughly assessed.

This working paper is the result of a scoping study that was carried out in the initial phase of Smart Tree Invest project in Buol, Central Sulawesi, Indonesia. The scoping study stage has three main objectives:

1. To assess the condition of ecosystem services in Buol landscape, i.e. the regulating services of carbon sequestration, tree-diversity in the various land-use systems, and the hydrological situation;

2. To assess the potential challenges in developing a plausible PES scheme by exploring and analysing the perception and perspective of local stakeholders of their landscape, including farmers' vulnerability; and

3. To prospect a potential PES scheme based on the existing condition of ecosystem services.

We refer to the framework of cascades flow of ecosystems services described in Braat and de Groot (2012), who stated that ecosystem services are only beneficial and of value to humans with some investment of energy or labour by humans in combination with natural processes energy (Figure 1). In practice, however, human intervention often reduces the capacity of the ecosystem to perform regulating services. Thus, management to restore or maintain the regulating services is necessary. Within this framework, our study focuses on assessing the ecosystems functions at landscape level (A) and how they are used by the local communities (B) leading to a recommendation on potential co-investment schemes to restore, maintain, and enhance ecosystem services (C).

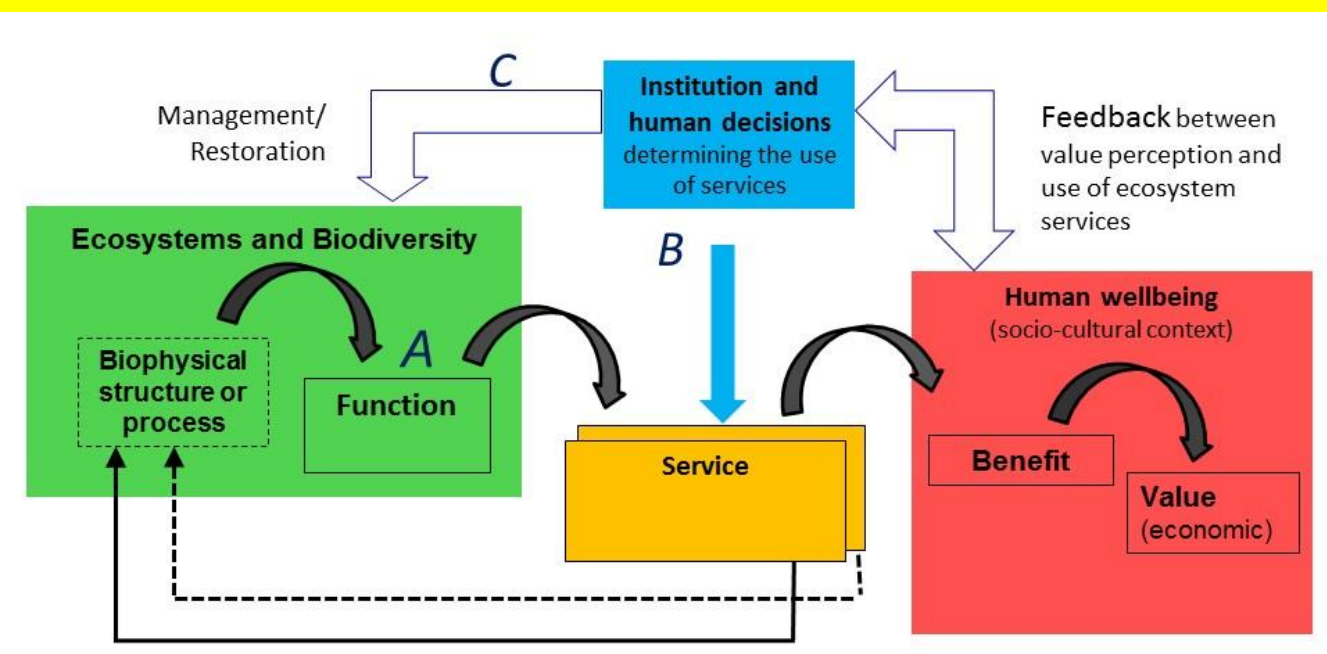

Figure 1. The framework of the current study, based on the cascade model of ecosystem services (modified from Braat and de Groot 2008). 
There are three companion papers that provide sources of information for this paper: (i) Wijaya et al (2015), who explore the historical land cover/use dynamics in the area including the potential landscape carbon; (ii) Rahayu et al (2015) who assess the use of trees by farmers including the potential tree diversity of each land-use system in Buol; and (iii) Amaruzaman et al (2015) that explore farmers' preference for trees to manage their landscape.

\section{Concepts and Methods}

\subsection{From payment to co-investment of ecosystem services}

The PES concept started around the turn of the millennium. PES involves land manager(s) being compensated (financially) for improving and maintaining the ecosystem services (ES) provided by the land (Wunder 2005; Leimona and Munawir 2012). Wunder (2005) suggests a definition of PES based on five criteria: 1) a voluntary transaction, where 2) well-defined services or land-use that secure the provision of such services 3) are being bought by at least one ES buyer or beneficiary from 4) at least one ES seller or provider, 5) if and only if the ES provider secures the provision of services through a certain conditionality. In its initial implementation, the definition provided by Wunder was understood as a market-based transaction, and 'payment' was often too narrowly comprehended as cash rewards.

From their experience in developing the PES schemes in Asia, van Noordwijk and Leimona (2010) concluded that a strict interpretation of the PES definition as realistic, conditional, and voluntary might be difficult to achieve in real-life situations. Instead, they suggest that PES schemes with a livelihood approach that considers the five types of capital (human, social, physical, financial, and natural) and their interactions, will have a better chance to succeed in its implementation.

Based on the conditionality of schemes, including trust and responsibility between stakeholders, van Noordwijk and Leimona (2010) characterized three typologies of PES: (i) the Commoditization of ES (CES), (ii) Compensation for the Skipped Opportunities (COS), and the (iii) co-investment in environmental stewardship (CIS). In a society where the motivation and the desire to be liked and well-regarded by others are still strong, PES schemes are more likely based on the concepts of 'shared responsibility' and 'mutual trust' where each stakeholder uses their financial and non-financial resources to co-invest in conservation activities. In these societies, 'co-investment' is the more suitable and likely to be implemented typology as it encourages people to participate and get involved. In co-investment schemes, compensation does not necessarily mean financial incentives; it can also come in the form of a contribution of time, in-kind resources, permits, programmes, etc. Furthermore, co-investment in the provision of ecosystem services offers more flexibility based on collaboration and mutual trust between the stakeholders in a given landscape. 


\subsection{Assessing the potential of PES schemes in Buol landscape}

The CaSAVA framework was implemented in this study as a step towards finding the most suitable form of PES for Buol district. The framework synthesizes local and scientific knowledge to identify existing livelihoods' assets (human, social, financial, physical, and natural capital) and deficits at multiple landscape scales. The information for the synthesis comes from multiple stakeholders, i.e. farmers, government officers, and scientists, and is designed to gain information on the way local stakeholders (including female and male farmers) buffer and adapt to both economic and climaterelated shocks and hazards (van Noordwijk et al 2013).

CaSAVA takes a landscape approach in acquiring information from stakeholders (Figure 2), whereby landscapes with similar environmental and socio-economic issues become the unit of analysis termed as cluster. A cluster preferably relates to a single governance unit (a district, sub-district, or village), to institutionally ease the development of co-investment schemes. In this study, clusters that were identified became the project action-research sites. Throughout this paper, 'cluster' and 'actionresearch site' are used interchangeably.

The study described in this paper entails the implementation of step 1 (Vulnerability assessment) and 2 (SWOT analysis) of the overall framework. The CaSAVA framework involves activities at two scales: cluster and district, and has two focusses of assessment: landscape and community. The method has been applied by the World Agroforestry Centre (ICRAF) in south and southeast Sulawesi (Paramita 2013). The application in Buol, central Sulawesi adopts similar activities with minor adjustments to the specificity of the landscape and community. The details of each activity are described below.

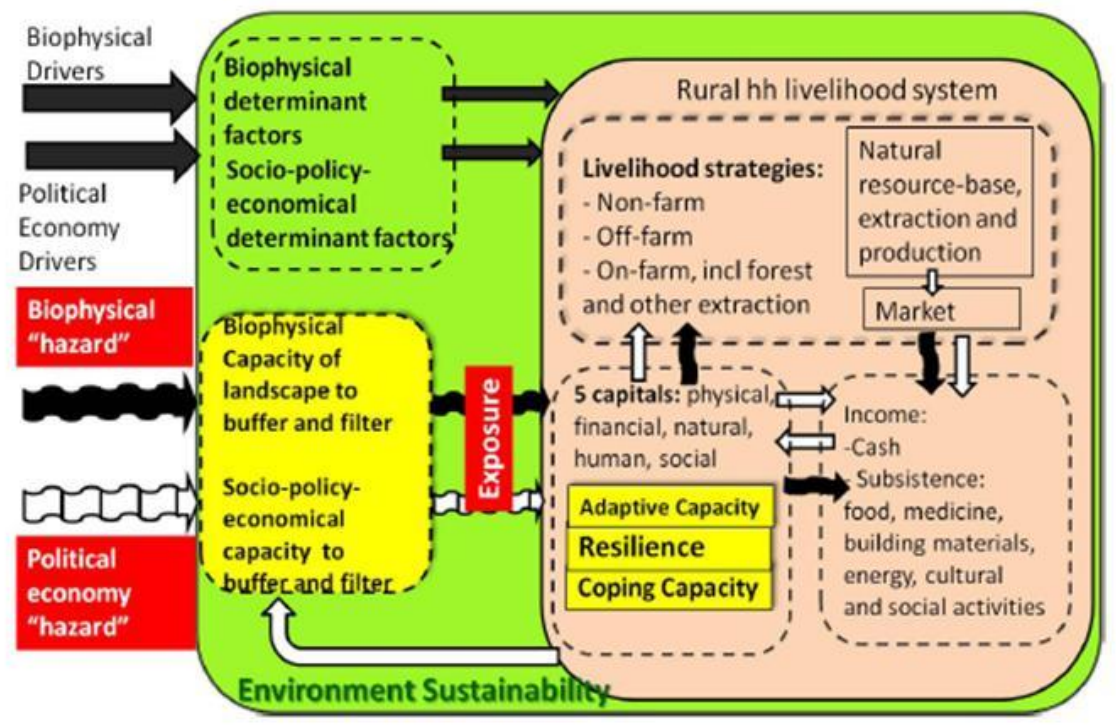

Figure 2. Capacity Strengthening Approach to Vulnerability Assessment (CaSAVA) framework. Source: Dewi et al (2013) 


\subsubsection{Assessing the provisioning of ecosystem services}

As an initial exploration, we focus on the condition of 3 ecosystem-regulating services in Buol district: (i) landscape carbon stocks, (ii) tree diversity, and (iii) hydrological functions. These 3 ecosystem services are influenced by farmer activity in the landscape.

\subsubsection{Carbon sequestration}

To assess the potential carbon sequestration of Buol District, we use the Rapid Carbon Stocks Appraisal (RaCSA) approach (Hairiah et al 2011) This approach monitors change in carbon stocks to estimate carbon sequestration or emissions based on information of land use/cover change (or a series of land cover maps) and plot-level carbon density of each land cover type. Table 1 provides a list of existing land cover/use maps in Buol and their associated plot-level carbon density, based on a survey carried out in 2014 (Wijaya et al 2015).

Table 1. Land use/cover types and its carbon stock used in Buol District.

\begin{tabular}{lll}
\hline No & Land use cover & $\begin{array}{l}\text { C stock }^{*} \\
\left(\mathbf{M g ~ C ~ h a}^{-1}\right)\end{array}$ \\
\hline 1 & Forest & 165.7 \\
\hline 2 & Mangrove & $57.5^{\mathrm{a}}$ \\
\hline 3 & Agroforestry (clove/cacao/timber) & 75.4 \\
\hline 4 & Coconut & 84.1 \\
\hline 5 & Oil palm plantation & $41.5^{\mathrm{a}}$ \\
\hline 6 & Shrub & 3.4 \\
\hline 7 & Annual crop & 1 \\
\hline 8 & Rice field & $1.0^{\mathrm{a}}$ \\
\hline
\end{tabular}

\subsubsection{Tree diversity}

A tree diversity survey was conducted in seven tree-based systems found in Buol district: logged-over forest, sago forest, complex agroforest, cacao agroforest, coconut agroforest, clove agroforest, and monoculture teak. As a reference, we also measured the tree-diversity of undisturbed forest in the adjacent district of Toli-Toli. The survey used the Quick Biodiversity Survey (QBS) approach. Rahayu et al (2015) provided details of the survey methodology.

We used two indicators of tree diversity: (i) species richness, using the Shannon-Wiener Diversity Index, and (ii) species composition using the Bray-Curtis Distance that represents the dissimilarity of species across different land-use systems.

\subsubsection{Hydrological functions}

An initial exploration to find rainfall and river flow data resulted in poor quality data. Therefore, an assessment on hydrological information will be based on local knowledge. A detailed description of 
the approach used is provided in the section on vulnerability assessment at local community level below.

\subsubsection{Key informant interviews and focus group discussion at district level}

The key-informant-interviews (KII) were carried out specifically to identify potential clusters or action-research sites where ES co-investment scheme(s) will be developed and implemented. The interviews also aim to have a general understanding of environmental and livelihood issues in the district. A Focus Group Discussion (FGD) with local policy-makers and natural resource managers was carried out in the beginning of the project in order to gain their feedback on the potential cluster sites and development activities that have been carried out in the area.

Table 2. Number of participants from local government at sub-district and village levels, and number of village representatives in each cluster

\begin{tabular}{|c|c|c|c|c|c|}
\hline Group & Participants & District & Upstream & Midstream & Coastal \\
\hline \multirow{3}{*}{ Male } & District officers & 62 & - & - & - \\
\hline & Sub-district and village officers & - & 10 & 8 & 10 \\
\hline & Villagers & - & 13 & 10 & 17 \\
\hline \multirow{3}{*}{ Female } & District officers & 24 & - & - & - \\
\hline & Sub-district and village officers & - & 7 & - & 2 \\
\hline & Villagers & - & 6 & 6 & 10 \\
\hline
\end{tabular}

\subsubsection{Vulnerability Assessment}

The vulnerability assessment is done through a focus group discussion (FGD), focusing on the roles of the five types of capital (assets) in livelihood strategies under shock and hazard conditions, in particular on:

1. direct use of local biodiversity;

2. usage of water and the dynamics of its quantity and quality;

3. selection of farming systems and tree species; and

4. the resilience of farming systems to shocks, and immediate responses (coping) and long-term responses (adapting) to the impacts of shocks;

The FGD discussion followed a structured discussion with a list of questions guided by the facilitator. The list was developed to allow the FGD participants to gradually become aware of their landscape. The participants were split into four (4) thematic groups, where each of the thematic groups divided into male and female group (Table 1). The purpose of this gender separation is to obtain information from both men's and women's perspectives. 


\subsubsection{Strength, Weakness, Opportunity and Threat (SWOT) analysis}

As suggested by its name, a SWOT analysis is a popular and common method to identify strengths, weaknesses, opportunities, and threats for a particular situation. In this study, a SWOT analysis was carried out at cluster level to identify issues that represent conditions on the ground. In particular, it aims (i) to obtain information from local stakeholders on the potential areas (strengths) as well as problematic areas (weaknesses) in their villages and landscape and (ii) to make local stakeholders think about the potential opportunities for conservation and livelihood strategies and potential combinations, while also anticipating the possible threats. In Buol, the analysis was facilitated by ICRAF and carried out by cluster representatives from (i) villages (that form a cluster), and (ii) the local village and sub-district governments that are considered knowledgeable and able to represent the local context (Table 2). In each cluster, the participants of the SWOT discussion were divided into three groups: two male groups and one female group, except in the coastal cluster where participants were limited. The representatives from villages were selected from the previous FGD for vulnerability assessment that was considered active and knowledgeable about their landscape, including the relevant socio-economic and development issues. Prior to the SWOT analysis, the results from the vulnerability assessment were shared with the stakeholders. 
Table 3. Number of farmers participating in the FGD for vulnerability assessment in each action-research site in Buol

\begin{tabular}{|c|c|c|c|c|c|c|c|}
\hline \multirow[b]{2}{*}{ Thematic group } & \multirow[b]{2}{*}{ Gender } & \multicolumn{2}{|l|}{ Upstream } & \multicolumn{2}{|l|}{ Midstream } & \multicolumn{2}{|l|}{ Coastal } \\
\hline & & $\begin{array}{l}\text { Number of } \\
\text { Participants }\end{array}$ & Livelihood & $\begin{array}{l}\text { Number of } \\
\text { Participants }\end{array}$ & Livelihood & $\begin{array}{l}\text { Number of } \\
\text { Participants }\end{array}$ & Livelihood \\
\hline \multirow[t]{3}{*}{ Biodiversity } & Male & 7 & Farmers & 3 & Farmers, & 7 & Farmers and fishermen \\
\hline & & & & & $\begin{array}{l}\text { Ex-village officers, farmer } \\
\text { group leaders }\end{array}$ & & \\
\hline & $\begin{array}{l}\text { Femal } \\
\text { e }\end{array}$ & 7 & $\begin{array}{l}\text { Farmers and } \\
\text { housewives }\end{array}$ & 5 & Farmers & 3 & $\begin{array}{l}\text { Farmers, } \\
\text { fishermen and miners }\end{array}$ \\
\hline \multirow{2}{*}{$\begin{array}{l}\text { WRESH and } \\
\text { SERI }^{*}\end{array}$} & Male & 9 & Farmers & 8 & Farmers & 6 & Farmers \\
\hline & $\begin{array}{l}\text { Femal } \\
\text { e }\end{array}$ & 6 & $\begin{array}{l}\text { Farmers, LPM } \\
\text { leader, } \\
\text { housewives }\end{array}$ & 6 & Farmers and housewives & 5 & $\begin{array}{l}\text { Farmers, } \\
\text { retired workers, village } \\
\text { cadres and LPM member }\end{array}$ \\
\hline \multirow{2}{*}{$\begin{array}{l}\text { Tree Preference } \\
\text { and Farming } \\
\text { Systems }\end{array}$} & Male & 8 & $\begin{array}{l}\text { Farmers and } \\
\text { private employee }\end{array}$ & 8 & Farmers & 9 & Farmers and fishermen \\
\hline & $\begin{array}{l}\text { Femal } \\
\mathrm{e}\end{array}$ & 5 & Housewives & 5 & Farmers and teachers & 5 & Farmers and housewives \\
\hline \multirow{2}{*}{$\begin{array}{l}\text { Drivers of Land } \\
\text { Use Change }\end{array}$} & Male & 8 & Farmers & 6 & Farmers & \multirow{2}{*}{8} & \multirow{2}{*}{ Farmers } \\
\hline & Female & 6 & Housewives & 7 & Farmers & & \\
\hline
\end{tabular}

*WRESH: Water Resources and Environmental Service Hazards; SERI: Shock, Exposure, Response and Impact 


\section{The study site: Buol district}

\subsection{Geographic location, general socio-economic and environmental condition}

Sulawesi is one of the five large islands in Indonesia. The island is considered to be a transition zone ${ }^{1}$ in terms of flora and fauna between Asia and Australia. Thus, in addition to being biologically unique, Sulawesi also has unique climatic characteristics compared to other regions in Indonesia. Sulawesi is divided into 6 provinces; one of them is Central Sulawesi. The Human Development Index (HDI) of the provinces in Sulawesi is lower than the national average. In 2011, the national HDI average was 78.9, whereas for Central Sulawesi's was 71.6, ranking 22 of the 34 provinces of Indonesia. The life expectancy for Central Sulawesi was 68.9, which is below the national average of 69.8, while the region's economic growth for 2006-2010 was 8.18\%.

Buol is a district situated in the northern part of Central Sulawesi, roughly $806 \mathrm{~km}$ or an 18-hour drive from Palu, the province's capital city (Figure 3). Buol's total area is approximately 3,562 km², bordering Toli-Toli district to the west and Gorontalo province to the east. Buol's land use varies considerably, ranging from mountainous forests in the south to tree-based systems and agriculture in the centre, and mangrove ecosystems along the coastal areas in the north. The main tree-based systems managed by farmers were complex agroforestry systems, and clove, teak, and coconut plantations, while the main agriculture systems are irrigated paddies and dryland agriculture, including maize and vegetables (Wijaya et al 2015). Since the mid-90s, oil palm plantation started to encroach on the forest areas.

${ }^{1}$ Also termed as Wallacea zone, named after the famous naturalist Alfred Russel Wallace 


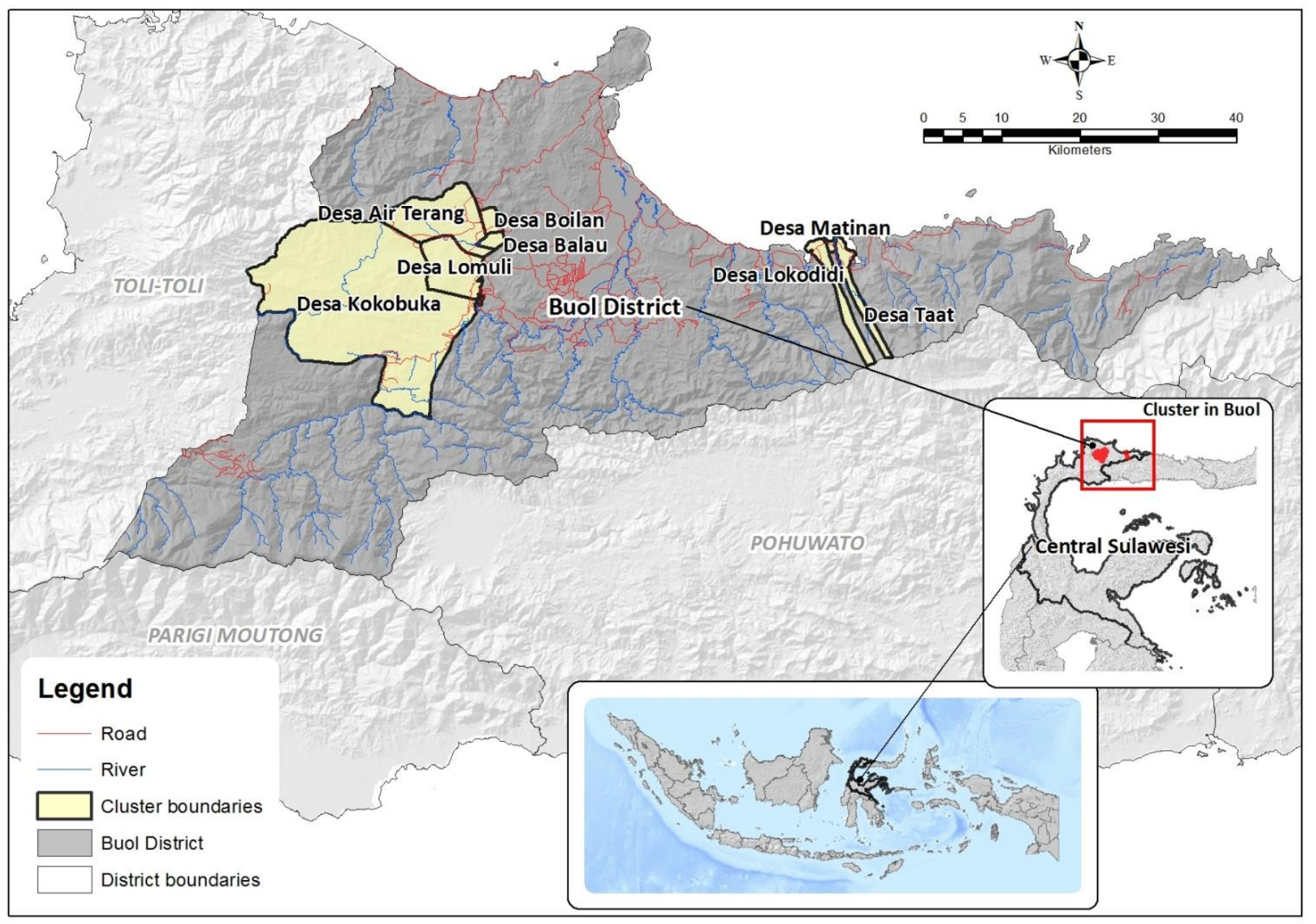

Figure 3. Location of Buol district within Central Sulawesi and the three action-research sites where this study was carried out. 
The district was established in 1999 after it split off from Toli-Toli district. The deforestation rate for the 2000-2010 period was $11 \%$, one of the highest in the province. By 2010, forest cover in Buol was only $11 \%$, while agriculture systems comprise $52 \%$ of the total landscape. The total gross domestic product (GDP) of Buol was USD 175,348 in 2012, which calculates to USD 1.3 per capita per day, which is lower than the province's average of USD 1.9 per capita per day. The population density in the sub-districts ranges from $7-134 \mathrm{~km}^{-2}$ with an average of $24 \mathrm{~km}^{-2}$.

The Buol watershed is the main catchment in the district, comprising $1662 \mathrm{~km}^{2}$ or almost a third of the district area (Figure 4). The dominating soil type in the upstream area is Inceptisols, while Ultisols are commonly found in the downstream area. The average monthly river discharge of the Buol River and the average monthly rainfall in the Buol watershed are shown in Figure 5. The rainy season peaks in February-June, while the dry season lasts less than three months during the August-October period.

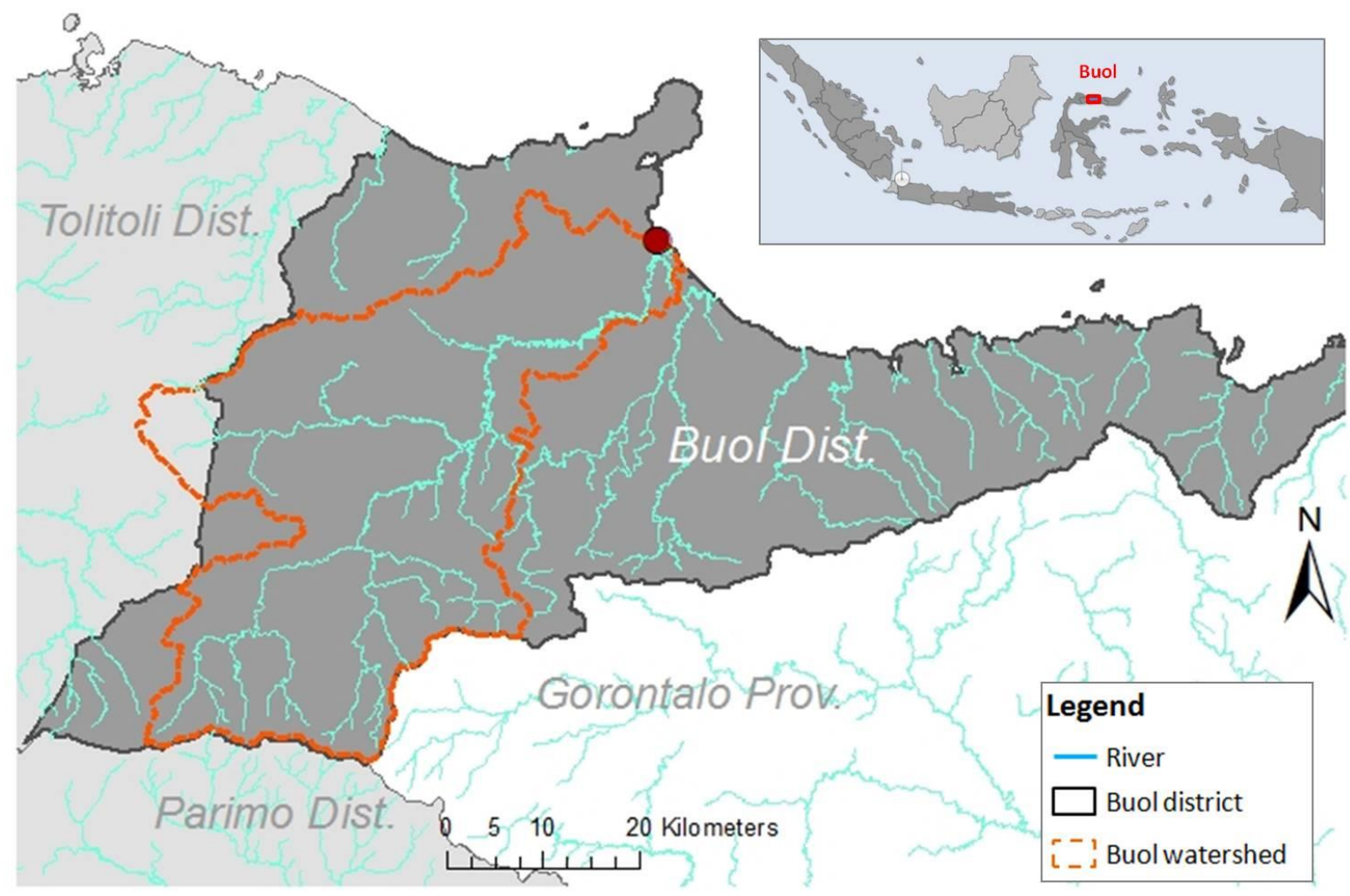

Figure 4. The Buol watershed with the location of the rainfall and river discharge station. 

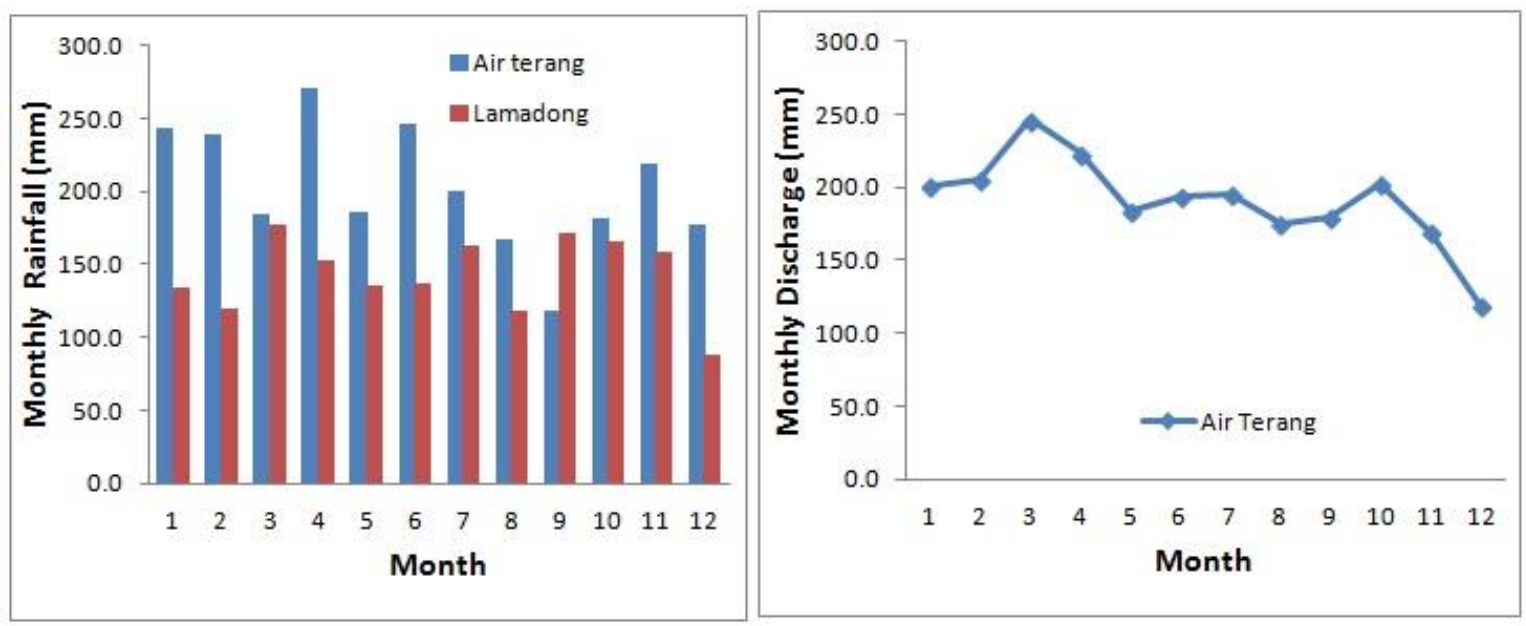

Figure 5. The average monthly rainfall and monthly discharge in Buol, measured in the Buol watershed.
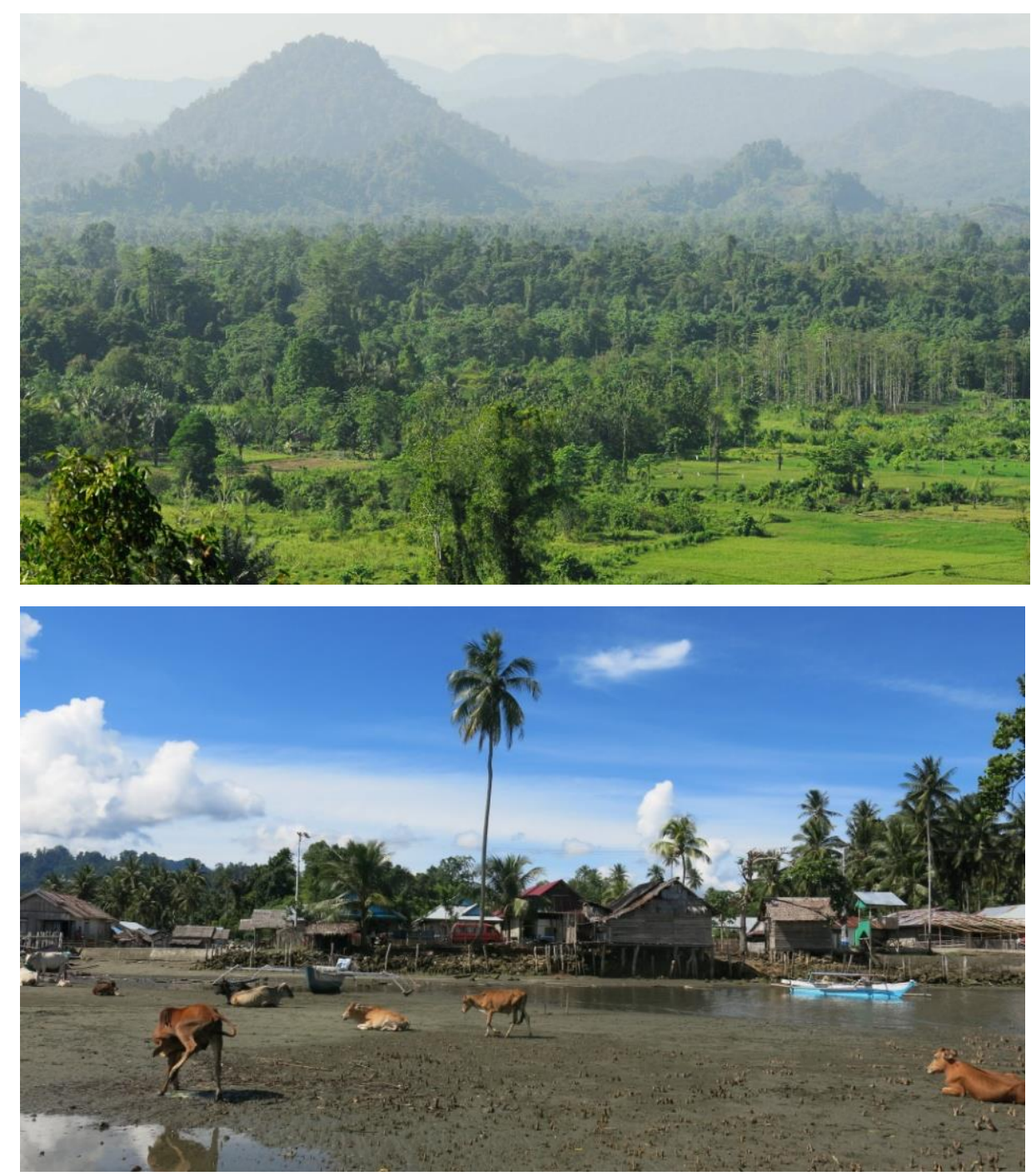

Photo 1. The landscape of Buol: (a) the upland, and (b) the coastal areas 


\subsection{Cluster Identification}

We interviewed ten key informants: eight village officers and ten local government staff. Based on the interviews, we decided to focus on two main areas and issues: (1) the coastal areas with loss of coastal vegetation/mangrove, and hence coastal abrasion as the environmental issue, and (2) the upper catchment areas of the Buol watershed. The upper catchment areas have two distinct environmental issues: (i) flooding and river bank collapse in the lower part (still within the upper catchment), and lack of water for irrigation in the upper part. This is why the Smart Tree-Invest project is working in three research-action sites/clusters in Buol, two sites of which are located in the Buol watershed, encompassing five villages: Kokobuka, Lomuli, Air Terang, Boilan, and Balau of the Tiloan subdistrict, while the third site lies in the coastal area comprising three villages: Taat, Matinan, and Lokodidi of Gadung sub-district (Figure 4, Table 1). Further details are provided in Amaruzaman et al (2015). 
Table 4. General characteristics of the action-research sites of the Smart Tree-Invest project in Buol district.

\begin{tabular}{|c|c|c|c|c|c|c|c|}
\hline $\begin{array}{l}\text { Sub- } \\
\text { district }\end{array}$ & Cluster & Village & Agricultural systems & Community type & $\begin{array}{l}\text { Main } \\
\text { livelihood } \\
\text { options }\end{array}$ & $\begin{array}{l}\text { Environmental } \\
\text { issues }\end{array}$ & Access \\
\hline \multirow[t]{2}{*}{ Tiloan } & Upstream & $\begin{array}{l}\text { Kokobuka } \\
\text { Lomuli }\end{array}$ & $\begin{array}{l}\text { annual crops (maize, rice, } \\
\text { vegetables, tubers) } \\
\text { timber systems } \\
\text { cacao systems (mostly } \\
\text { abandoned) }\end{array}$ & $\begin{array}{l}\text { Transmigrant }{ }^{2} \text {, mostly from } \\
\text { Java and Bali }\end{array}$ & $\begin{array}{l}\text { Agricultural } \\
\text { activities }\end{array}$ & $\begin{array}{l}\text { Lack of water for } \\
\text { irrigation, erosion in } \\
\text { newly opened oil palm } \\
\text { plantation areas }\end{array}$ & $\begin{array}{l}\text { Difficult, stone } \\
\text { and dirt road, } \\
\text { undulating } \\
\text { terrain }\end{array}$ \\
\hline & Midstream & $\begin{array}{l}\text { Balau } \\
\text { Boilan } \\
\text { Air } \\
\text { Terang }\end{array}$ & $\begin{array}{l}\text { annual crops (maize, rice, } \\
\text { vegetables, tubers) } \\
\text { timber systems } \\
\text { cacao systems }\end{array}$ & $\begin{array}{l}\text { Mixed between } \\
\text { transmigrant, from Java } \\
\text { and Bali. }\end{array}$ & $\begin{array}{l}\text { Agricultural } \\
\text { activities }\end{array}$ & $\begin{array}{l}\text { Flooding, river bank } \\
\text { collapse }\end{array}$ & $\begin{array}{l}\text { Moderate, some } \\
\text { parts of the road } \\
\text { are in bad } \\
\text { condition }\end{array}$ \\
\hline Gadung & Coastal & $\begin{array}{l}\text { Matinan } \\
\text { Lokodidi } \\
\text { Taat }\end{array}$ & $\begin{array}{l}\text { cacao } \\
\text { clove } \\
\text { fruit trees (mixed systems) } \\
\text { rice fields (few) }\end{array}$ & $\begin{array}{l}\text { Mostly local people, some } \\
\text { spontaneous migrants from } \\
\text { other areas in Sulawesi } \\
\text { such as Gorontalo, and } \\
\text { South and North Sulawesi }\end{array}$ & $\begin{array}{l}\text { Agricultural } \\
\text { activities. } \\
\text { Fishing and } \\
\text { mining }\end{array}$ & $\begin{array}{l}\text { Coastal vegetation } \\
\text { degradation, coastal } \\
\text { abrasion, increased } \\
\text { sea water levels }\end{array}$ & $\begin{array}{l}\text { Easy, along } \\
\text { good-quality } \\
\text { provincial road }\end{array}$ \\
\hline
\end{tabular}

${ }^{2}$ The transmigration programme in Indonesia (from Dutch, transmigratie) was an initiative of the Dutch colonial government, which was later continued by the Indonesian government to move landless people from densely populated areas of Indonesia Java to the other islands such as Sumatera, Kalimantan, Sulawesi, Papua that are less densely populated. . The stated purpose of this programme was to reduce overpopulation on Java, to provide opportunities for hard-working poor people, and to provide a workforce to better utilize the natural resources of the outer islands. People who participated in the programme are called transmigrants. 


\section{Results}

\subsection{Ecosystem services condition}

\subsubsection{Landscape carbon stocks}

Until 2014, Buol was still able to maintain 70\% of its forest cover (Figure 6A) even though there was a substantial increase in oil palm plantations and paddy areas. The loss of forest translated into a reduction of landscape carbon stocks (Figure 6B).

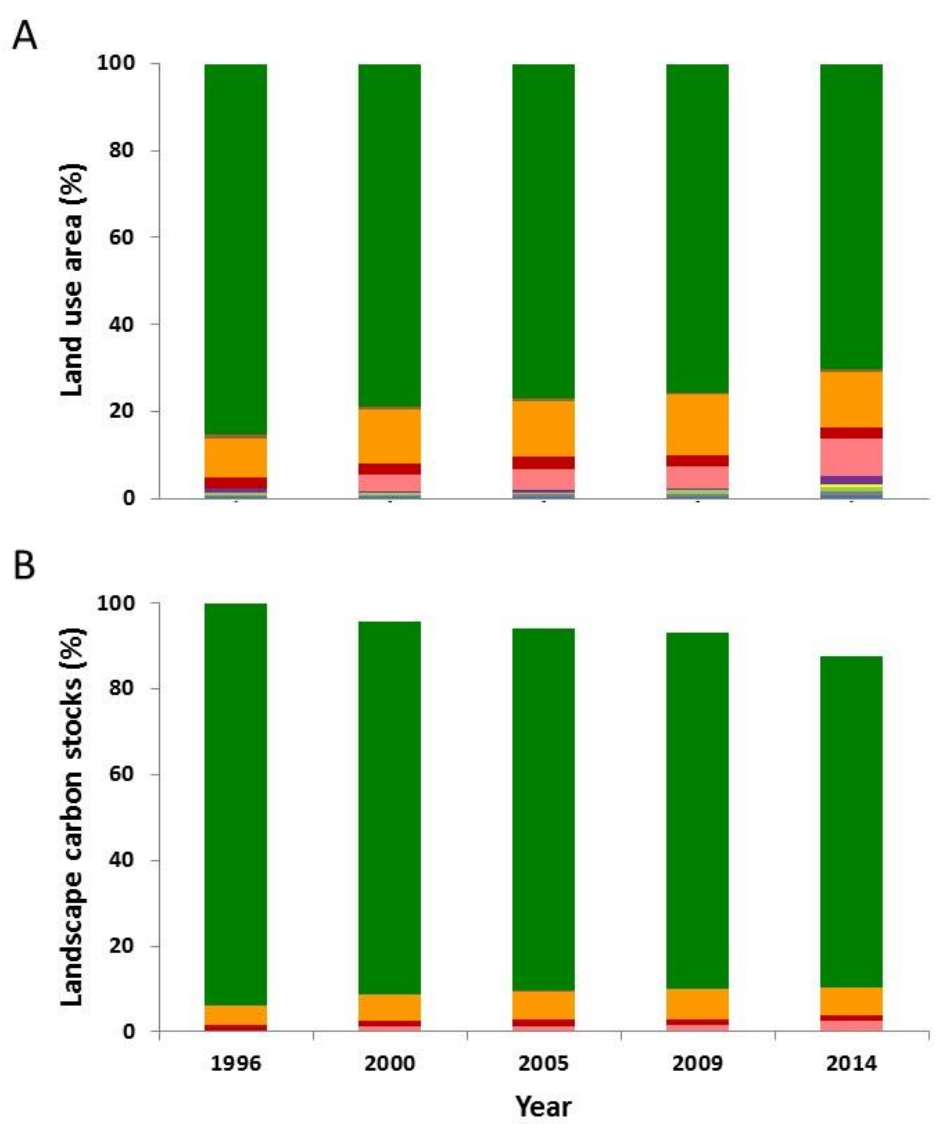

Figure 6. Distribution of land use/cover types in Buol district from 1996-2014 (A) and the associated distribution of carbon stocks (B). The reference point for the landscape carbon stocks is 1996. 
Table 5. Carbon sequestration, carbon emission, and net $\mathrm{CO}_{2}$-emissions in Buol district for the period 1996-2014

\begin{tabular}{|c|c|c|c|}
\hline Description and unit & $\begin{array}{l}\text { Carbon } \\
\text { sequestration }\end{array}$ & Carbon emissions & $\begin{array}{l}\text { Net carbon } \\
\text { emission }\end{array}$ \\
\hline \multicolumn{4}{|l|}{ Total across landscape } \\
\hline $\operatorname{Tg}$ & 0.25 & 7.39 & 7.14 \\
\hline $\mathrm{CO}_{2}$ equivalent $\mathrm{Tg}$ & 0.07 & 2.01 & 1.94 \\
\hline \multicolumn{4}{|l|}{ Annual } \\
\hline Mg year-1 $^{-1}$ & 14,054 & 410,4031 & 396,349 \\
\hline $\mathrm{CO}_{2}$ equivalent $\mathrm{Mg}$ year-1 & 3,833 & 111,928 & 108,095 \\
\hline \multicolumn{4}{|l|}{ Annual per hectare } \\
\hline Mg year-1 ha ${ }^{-1}$ & 0.04 & 1.19 & 1.06 \\
\hline $\mathrm{CO}_{2}$ equivalent $\mathrm{Mg}$ year-1 $\mathrm{ha}^{-1}$ & 0.01 & 0.29 & 0.28 \\
\hline
\end{tabular}

From 2009-2014, net carbon emissions in Buol reached 1.9 million $\mathrm{Mg} \mathrm{CO}_{2}$-eq year ${ }^{-1}$, which is the result of the emission of 2 million $\mathrm{Mg} \mathrm{CO}_{2}$-eq year ${ }^{-1}$ and the sequestration of as much as $68,991 \mathrm{Mg}$ $\mathrm{CO}_{2}$-eq year-1 (Table 4). The land conversion from forest, and the conversion from agroforestry to rice field and oil palm were the greatest contributors to carbon emissions. The sequestration of carbon is due to the conversion of cropland to cacao, clove, or timber systems.

\subsubsection{Tree diversity}

Forest in Buol, albeit disturbed and logged, still provides better habitats for trees than tree-based systems managed by farmers can (Figure 7). The high Shannon-Wiener diversity index for undisturbed forest means that there is quite a high diversity of tree species for all the vegetation stages (seedling, sapling, pole, and tree). In the case of trees, diversity is even higher than what is found in samples of undisturbed forest in the neighbouring district of Toli-Toli. However, analysis of the species composition of existing land-use systems showed that only few of the tree species found in the undisturbed forest overlap with species found in systems outside the forest (Table 6). Farmers' management such as weeding had prevented the non-domesticated tree species from growing further.

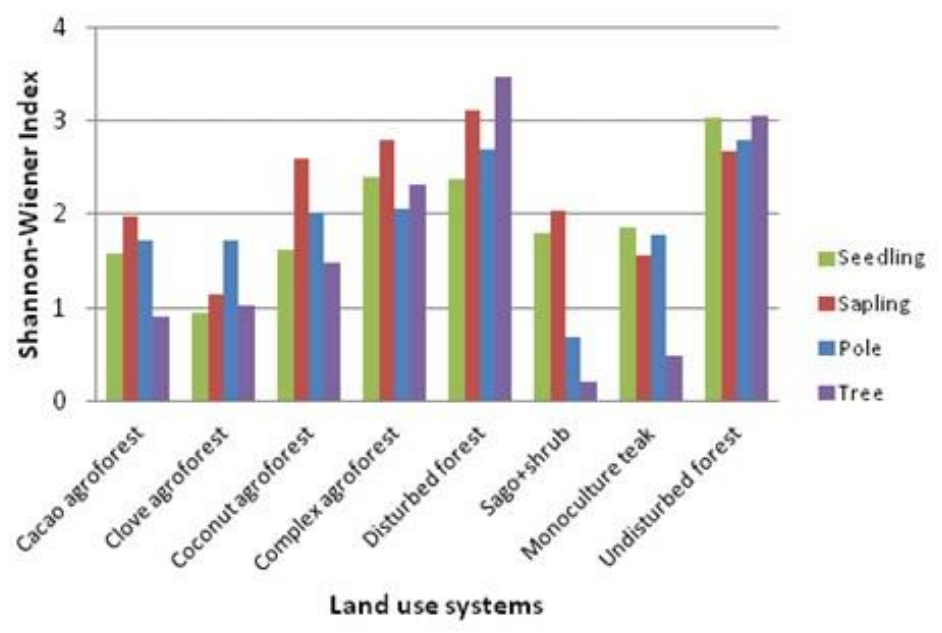

Figure 7. Shannon-Wiener Diversity Index of seedling, sapling, pole, and tree in the various land-use systems in Buol. 
Table 6. Similarity of the tree species across land-use systems using Bray-Curtis Index

\begin{tabular}{lllllllll}
\hline Land uses & Cacao & Clove & Coconut & Complex & Disturbed & Sago & Teak Undisturbed \\
\hline Cacao & 1 & & & & & & & \\
Clove & 0.09 & 1 & & & & & & \\
Coconut & 0.10 & 0.30 & 1 & & & & & \\
Complex & 0.53 & 0.17 & 0.33 & 1 & & & & \\
Disturbed & 0.02 & 0.0 & 0.01 & 0.04 & 1 & & & \\
Sago & 0.01 & 0.0 & 0.02 & 0.02 & 0.00 & 1 & & \\
Teak & 0.06 & 0.01 & 0.09 & 0.07 & 0.03 & 0.0 & 1 & \\
Undisturbed & 0.01 & 0.0 & 0.0 & 0.03 & 0.09 & 0.00 & 0.00 & 1 \\
\hline
\end{tabular}

\subsubsection{Hydrological condition}

\subsubsection{Water use and hydrological issues}

We categorized community use of water as domestic and productive. Domestic entails use of water for daily activities such as cooking and washing, while productive use is dominantly for agricultural activities and a small number of off-farm activities such as producing soya bean cake ('tempe'). The water sources are mostly the river and dug wells, both in normal and drought situations (Figure 8). In villages that were part of the community water project $^{3}$ (PAMSIMAS or PNPM), infrastructure built by the projects had also become an important source of water. It appeared that most springs were affected by drought.

\footnotetext{
${ }^{3}$ PAMSIMAS is an abbreviation of Penyedian air minum dan sanitasi berbasis masyarakat or Community-based drinking water and sanitation; PNPM is Program Nasional Pemberdayaan Masyarakat or National programme of community empowerment
} 


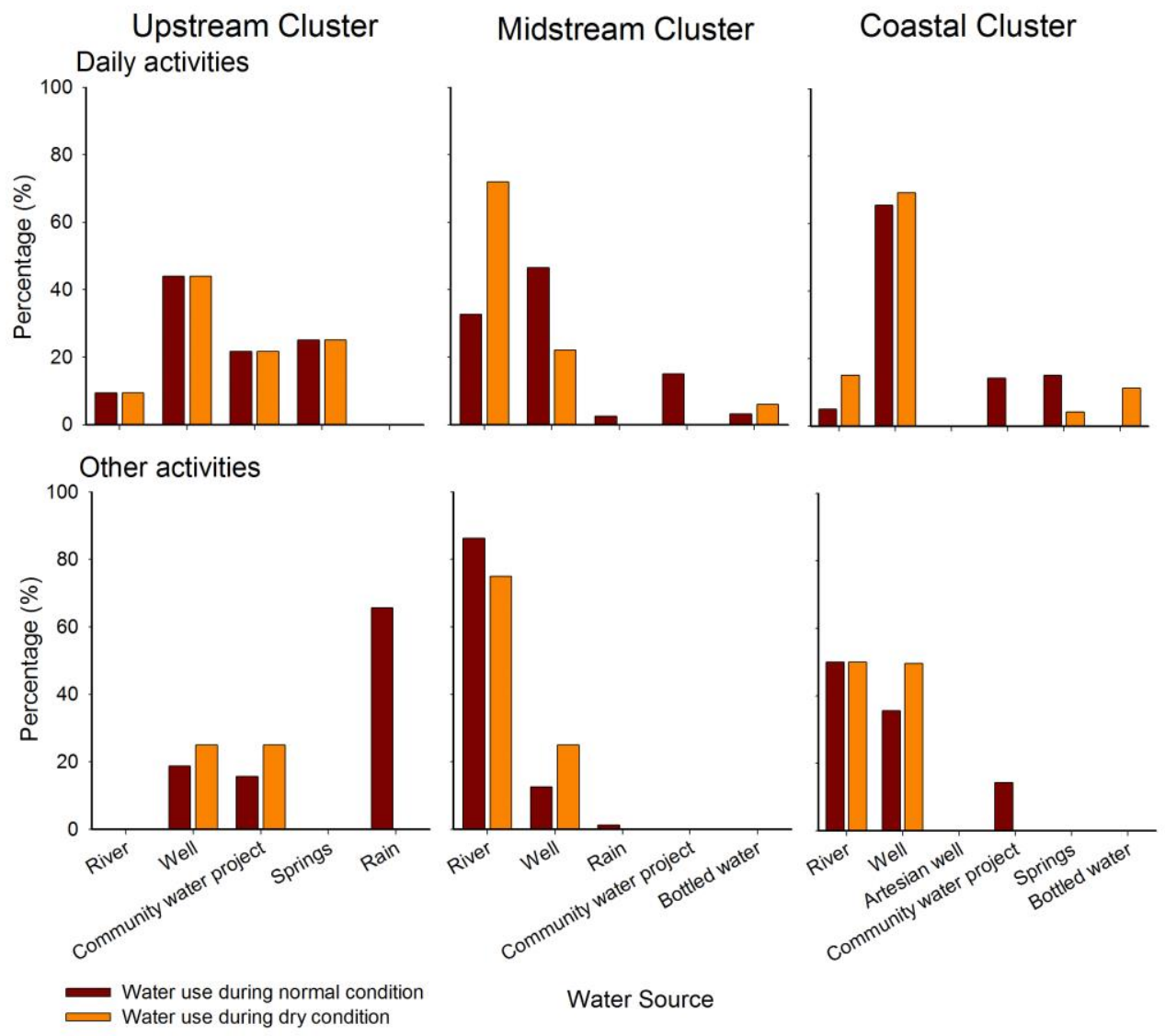

Figure 8. Water sources for different uses in each action-research site under normal conditions and in the drought season.

\subsubsection{Hydrological condition and issues}

The main water issues experienced by the community were mostly related to quality and quantity (Table 7). All groups found quality to be the number-one water-related problem, except for the male groups in Kokobuka village located furthest upstream: unpredictable rainfall patterns were their main concern.

Table 7. Rank of hydrological problems in each action-research site cluster, differentiated by gender, with 1 being most problematic and the first priority to be solved. Symbol $\sqrt{ }$ means that the issue is considered problematic but of lower priority.

\begin{tabular}{lllllllll}
\hline \multirow{2}{*}{ Hydrological Issues } & \multicolumn{2}{l}{ Upstream } & \multicolumn{2}{c}{ Midstream } & \multicolumn{2}{c}{ Coastal } \\
& Male & Female & Male & Female & Male & Female \\
\hline \multirow{2}{*}{ Quality } & Muddy & $\sqrt{ }$ & 1 & 3 & 1 & 2 & 1 \\
& Odour & $\sqrt{ }$ & 5 & 1 & 5 & 4 & $\sqrt{ }$ \\
& Coloured & $\sqrt{ }$ & 2 & 4 & 3 & & 4 \\
& $\begin{array}{l}\text { High calcium } \\
\text { contamination }\end{array}$ & 4 & & & & & \\
& Pesticides pollution & 5 & 4 & & & 3 & \\
\hline
\end{tabular}




\begin{tabular}{|c|c|c|c|c|c|c|c|}
\hline \multirow{2}{*}{\multicolumn{2}{|c|}{ Hydrological Issues }} & \multicolumn{2}{|c|}{ Upstream } & \multicolumn{2}{|c|}{ Midstream } & \multicolumn{2}{|c|}{ Coastal } \\
\hline & & \multirow{2}{*}{$\frac{\text { Male }}{\sqrt{ }}$} & \multirow[t]{2}{*}{ Female } & \multirow{2}{*}{$\begin{array}{l}\text { Male } \\
5\end{array}$} & \multirow{2}{*}{$\begin{array}{l}\text { Female } \\
4\end{array}$} & \multirow[t]{2}{*}{ Male } & \multirow{2}{*}{$\begin{array}{l}\text { Female } \\
3\end{array}$} \\
\hline & Waste pollution & & & & & & \\
\hline & Brackish water & & & & & & 5 \\
\hline & Mercury contamination & & & & & 6 & \\
\hline & Rust contamination & & & & $\sqrt{ }$ & & \\
\hline \multirow[t]{3}{*}{ Quantity } & Drought & $\sqrt{ }$ & $\sqrt{ }$ & $\sqrt{ }$ & $\sqrt{ }$ & $\sqrt{ }$ & 2 \\
\hline & Floods & 2 & 3 & $\sqrt{ }$ & 2 & $\sqrt{ }$ & \\
\hline & Reduced water & $\sqrt{ }$ & & $\sqrt{ }$ & $\sqrt{ }$ & & \\
\hline \multirow[t]{3}{*}{ Others } & Broken pipe & & & $\sqrt{ }$ & & 5 & \\
\hline & Erosion & 3 & & 2 & & & \\
\hline & Unpredictable rainfall & 1 & & & & & \\
\hline
\end{tabular}

\subsection{FGD at district level}

The participants of the FGD at district level were district office staff (Table 2); hence the aim of the FGD was to gain insights in the main environmental and socio-economic issues in the districts, in particular in the two main areas: watershed and coastal region.

The participants identified pertinent main issues in the coastal region and five issues in the watershed (Table 8). The participants agreed that the district has the proper institutions and regulations at its disposal to solve the problems. However, the main challenges and constraints to solve problems were (i) the involvement and commitment of all stakeholders to participate in activities to tackle environmental and socio-economic issues, and (ii) achieving strong coordination between the relevant governmental institutions. Appendix 3 contains detailed notes on the FGD participants' perceptions of each problem's cause, the ideal situation, and efforts or programmes that have been carried out to solve these problems. The appendix also includes a list detailing the constraining factors in solving the problem, and ideal efforts that should have been conducted with the reasons why they have not.

Table 8. The main issues in coastal and watershed areas.

\begin{tabular}{|c|c|c|}
\hline Rank & Issues in coastal areas & Issues in watershed areas \\
\hline 1 & Mangrove deforestation & Land use/cover change \\
\hline 2 & Coastal abrasion & Sedimentation, river abrasion and erosion \\
\hline 3 & Poverty & $\begin{array}{l}\text { Lack of stakeholder (local community, NGO, local } \\
\text { government, public figures) involvement }\end{array}$ \\
\hline 4 & $\begin{array}{l}\text { Environment management of coastal } \\
\text { settlement (sanitation, health) }\end{array}$ & $\begin{array}{l}\text { River direction changes (flowing close to settlement } \\
\text { areas) }\end{array}$ \\
\hline 5 & Pollution of coastal environment & Poverty \\
\hline 6 & Illegal fishing & - \\
\hline
\end{tabular}




\subsection{Vulnerability assessment: Shock, Exposure, Response and Impact}

The FGD on shocks, exposure, response, and impact experienced by farmers in Buol was conducted at community level. We aimed to gain insights on the existing farmers' vulnerability and exposure to shocks, as well as their ability to buffer shocks and hence assess their current resilience. We categorized the shocks into two categories: natural disasters and extreme events. Natural disasters refer to biophysical shocks, while extreme events refer to socio-economic factors that can influence the community in particular farmers' livelihoods. The ideal responses to shocks mentioned by farmers represent the potential buffer, while farmers' current activities to reduce impact represent the existing buffer. The extent of buffer measured the current exposure of farmers to shocks.

Based on the discussion with farmers, flood and pest disease were the main shocks experienced by the farmer community in Buol (Table 9), while the extreme events were mainly related to shocks that affected their agricultural activities such as decreased product prices and scarcity of fertilizer. The increase in food price also affects the farmers' livelihoods (Table 10). Farmers' knowledge on better farming management with institutional support from the competent rural advisory office and the agricultural office are potential buffers to reduce the exposures to pests and diseases (Table 11). The community in the midstream cluster expected that, with better river infrastructure, flooding and river meandering could be avoided.

The list of buffers and responses could become the starting point for the development of coinvestment activities to increase resilience, improve the economy of the community and the environmental condition of the landscape. 
Table 9. The natural disasters experienced by the communities, the impact on the community, and community responses.

\begin{tabular}{|c|c|c|c|c|c|c|c|c|c|}
\hline \multirow{2}{*}{$\begin{array}{l}\text { Natural } \\
\text { disasters }\end{array}$} & \multirow[t]{2}{*}{ Cluster } & \multicolumn{4}{|l|}{ Drivers } & \multicolumn{4}{|l|}{ Impacts } \\
\hline & & Cause & Response & Ideal response & Barriers & Impact & Response & Ideal response & Barriers \\
\hline \multirow[t]{2}{*}{ Flood } & Upstream & Heavy rain & $\begin{array}{l}\text { Building } \\
\text { embankment, } \\
\text { drainage } \\
\text { system, } \\
\text { trenches and } \\
\text { planting trees }\end{array}$ & - & - & \multirow{2}{*}{$\begin{array}{l}\text { Crop failure, } \\
\text { land } \\
\text { abandonment, } \\
\text { farming } \\
\text { disruption, loss } \\
\text { of access to } \\
\text { market, } \\
\text { economic loss, } \\
\text { ruined } \\
\text { infrastructure }\end{array}$} & - & - & Funds \\
\hline & Downstream & $\begin{array}{l}\text { Heavy rain, } \\
\text { river siltation } \\
\text { and } \\
\text { meandering, } \\
\text { land clearing, } \\
\text { development of } \\
\text { embankments } \\
\text { in the upstream } \\
\text { village }\end{array}$ & $\begin{array}{l}\text { Building } \\
\text { embankment, } \\
\text { planting } \\
\text { bamboo, } \\
\text { dredging the } \\
\text { river, } \\
\text { straightening } \\
\text { rivers }\end{array}$ & $\begin{array}{l}\text { Building } \\
\text { embankments } \\
\text { in the right } \\
\text { places }\end{array}$ & $\begin{array}{l}\text { Fund, land } \\
\text { tenure }\end{array}$ & & \multirow[t]{2}{*}{$\begin{array}{l}\text { Get loans, } \\
\text { rattan/NTFP } \\
\text { harvesting, } \\
\text { replant crops, } \\
\text { find other jobs }\end{array}$} & $\begin{array}{l}\text { Develop home } \\
\text { industry such } \\
\text { as fruit } \\
\text { processing }\end{array}$ & \\
\hline $\begin{array}{l}\text { Pests } \\
\text { and } \\
\text { disease }\end{array}$ & Coastal & $\begin{array}{l}\text { Knowledge } \\
\text { deficit on land } \\
\text { management, } \\
\text { different } \\
\text { planting time }\end{array}$ & $\begin{array}{l}\text { Use of } \\
\text { pesticide, } \\
\text { improving land } \\
\text { management }\end{array}$ & $\begin{array}{l}\text { Government } \\
\text { subsidizes/prov } \\
\text { ides pesticides } \\
\text { Improve } \\
\text { farmers' } \\
\text { capacity on } \\
\text { pest and } \\
\text { disease } \\
\text { management }\end{array}$ & Fund & $\begin{array}{l}\text { Reduction of } \\
\text { yield, income } \\
\text { and product } \\
\text { quality, crop } \\
\text { failure }\end{array}$ & & $\begin{array}{l}\text { Have extension } \\
\text { officers specific } \\
\text { for clove and } \\
\text { nutmeg } \\
\text { systems } \\
\text { Species } \\
\text { diversification } \\
\text { to diversify } \\
\text { commodities }\end{array}$ & $\begin{array}{l}\text { Extension } \\
\text { officer unable } \\
\text { to provide } \\
\text { support }\end{array}$ \\
\hline
\end{tabular}


Table 10. The extreme events experienced by communities, impact on the community, and community responses.

\begin{tabular}{|c|c|c|c|c|c|c|c|c|c|}
\hline \multirow{2}{*}{$\begin{array}{l}\text { Extreme } \\
\text { events }\end{array}$} & \multirow[t]{2}{*}{ Cluster } & \multicolumn{4}{|l|}{ Drivers } & \multicolumn{4}{|l|}{ Impacts } \\
\hline & & Cause & Response & Ideal response & Barriers & Impact & Response & Ideal response & Barriers \\
\hline \multirow[t]{3}{*}{$\begin{array}{l}\text { Increasing } \\
\text { food prices }\end{array}$} & Upstream & $\begin{array}{l}\text { Increasing fuel } \\
\text { price }\end{array}$ & - & - & - & $\begin{array}{l}\text { Unable to buy } \\
\text { food }\end{array}$ & \multirow{3}{*}{$\begin{array}{l}\text { Substitute rice } \\
\text { with cassava, } \\
\text { corn or sago }\end{array}$} & - & - \\
\hline & Midstream & $\begin{array}{l}\text { Market } \\
\text { scarcity, } \\
\text { increasing } \\
\text { transportation } \\
\text { cost }\end{array}$ & - & - & - & - & & - & - \\
\hline & Coastal & $\begin{array}{l}\text { Crop failure, } \\
\text { increasing fuel } \\
\text { price }\end{array}$ & - & - & - & $\begin{array}{l}\text { Increased } \\
\text { expenses }\end{array}$ & & $\begin{array}{l}\text { Raise the price } \\
\text { of own farm } \\
\text { products to } \\
\text { compensate }\end{array}$ & - \\
\hline \multirow[t]{2}{*}{$\begin{array}{l}\text { Scarcity of } \\
\text { fertilizer }\end{array}$} & Midstream & $\begin{array}{l}\text { The distributors } \\
\text { unable to meet } \\
\text { farmers' } \\
\text { demand for } \\
\text { fertilizer }\end{array}$ & - & - & - & - & - & - & - \\
\hline & Coastal & $\begin{array}{l}\text { Low supply in } \\
\text { the district }\end{array}$ & $\begin{array}{l}\text { Use manure, } \\
\text { burn around } \\
\text { the plot }\end{array}$ & - & - & - & $\begin{array}{l}\text { Decreased } \\
\text { yield and } \\
\text { income }\end{array}$ & - & - \\
\hline $\begin{array}{l}\text { Decreasing } \\
\text { rice price }\end{array}$ & Upstream & $\begin{array}{l}\text { Farmers are } \\
\text { bound by } \\
\text { agreement with } \\
\text { rice miller }\end{array}$ & $\begin{array}{l}\text { Negotiate with } \\
\text { the rice miller }\end{array}$ & $\begin{array}{l}\text { Cancel } \\
\text { agreement with } \\
\text { the rice miller }\end{array}$ & Fund & $\begin{array}{l}\text { Decreased } \\
\text { income }\end{array}$ & $\begin{array}{l}\text { Gather forest } \\
\text { products for } \\
\text { additional } \\
\text { income }\end{array}$ & $\begin{array}{l}\text { Add value to } \\
\text { products/yields } \\
\text { through further } \\
\text { processing }\end{array}$ & Lack of capital \\
\hline
\end{tabular}


Table 11. The shocks, exposure and buffers in the upland and coastal communities of Buol.

\begin{tabular}{|c|c|c|c|c|}
\hline \multirow[t]{2}{*}{ Shocks } & \multicolumn{3}{|l|}{ Exposure } & \multirow[t]{2}{*}{ Buffers } \\
\hline & Upstream & Midstream & Coastal & \\
\hline Flood & High & High & - & Better flood infrastructure \\
\hline Pests and disease & - & - & High & $\begin{array}{l}\text { Knowledge on farm management, } \\
\text { able rural advisory }\end{array}$ \\
\hline Increasing food price & Moderate & Moderate & Moderate & $\begin{array}{l}\text { Food diversity, higher and stable } \\
\text { income }\end{array}$ \\
\hline Scarcity of fertilizer & Low & High & High & Member of farmers' group \\
\hline $\begin{array}{l}\text { Decreasing agricultural } \\
\text { product price }\end{array}$ & High & - & - & $\begin{array}{l}\text { Better knowledge to add value to } \\
\text { products }\end{array}$ \\
\hline
\end{tabular}

\subsection{SWOT analysis}

The SWOT-analysis participants comprise the representatives of farmers, and the governments of villages and districts where the project is located. We asked the participants to provide key factors and issues that they think were their strengths, weaknesses, opportunities, and threats, and scored them according to their importance (from $1=$ least important to $4=$ very important). We then categorized the factors and issues according to the five types of livelihood capital: natural, infrastructure, human, social, and financial. The result showed that the participants in all clusters found natural capital to be their strength and opportunity, reflecting the rural and agricultural-based society of the village and villagers. For threats and weaknesses, the issues were broader than natural capital. All clusters, in particular the midstream cluster, found infrastructure to be their weakness. This is related to their wish for better flood management. The complete detailed result of the SWOT analysis is provided in Table Appendix 1.

\section{Discussion}

\subsection{Smallholder vulnerability}

The SWOT analysis revealed that farmers in Buol were exposed to constraints and risk on a day-today basis. There is a high risk of losing agricultural yield to due high pest and disease infestation in almost all types of crops, and tree-based systems. The hardest hit are the tree-based systems in Buol, such as cacao and clove systems. Coconut systems are the only remaining tree-systems that are still healthy, but even these are no longer productive as most are already old and need restoration or replanting. Timber trees are increasingly of interest to farmers, motivated by government-led regreening programme GERHAN (Gerakan Reboisasi Hutan dan Lahan, Land and Forest Re-greening 
Programme) to plant trees in and outside forests. However, mass planting is not currently attractive as access to timber markets outside Buol is low. Additionally, the current approach in government-led reforestation schemes usually entails providing seedlings with limited information or support in the management after planting. Hence, there is a high risk that the timber systems may perish and not reach maturity.

The most prominent environmental issues (flooding, river embankment collapse, landslide, and coastal erosion) are all related to watershed degradation and, to some extent, the change in rainfall patterns. The environmental degradation will directly impact the livelihoods of the community and the quality of life in general. Hence, any type of co-investment scheme developed in Buol must concurrently address the watershed degradation and improve agricultural systems managed by the farmers to reduce the risk faced by farmers and increase the ability to buffer against disasters or shocks.

\subsection{Challenges in developing co-investment schemes}

The prerequisite for PES development is the existence of threats to the environment, and the activities conducted by individuals or groups (ES providers) under the co-investment scheme must be able to alleviate the threats and maintain the ecosystem services. The activities as such are known as the conditionality. In Buol, the conditionality aspect is not fully understood yet, because the drivers of the environmental threats and issues need more clarification through further hydrological studies. In order to collect the hydrological data and analyse the issues, the stakeholders would need to co-invest in resources and time, as reliable data has not been made available yet. However, from the initial findings, we can define several activities that can improve the provision of ecosystem services in the coastal region and the watershed. Those activities can be conducted under the upcoming coinvestment scheme.

We have also addressed several challenges related with the financial, cultural, and institutional situation that might hinder the development of the co-investment scheme in Buol. Those challenges are elaborated as follows.

\subsubsection{Financial conditions}

As illustrated by the FGD and SWOT results, the community, in particular farmers, is relatively poor in most of the five types of livelihood capital. Hence, improving the livelihoods of Buol community farmers while restoring the ES is desirable to reduce the threats.

During this study, our observation did not find any potential ES beneficiaries, both in the coastal and watershed clusters, which would be able to provide financial incentives for the ES providers. The beneficiaries are most likely to be smallholder farmers and neighbours from the villages. The unavailability of ES beneficiaries that can provide financial incentives is the main challenge in setting up PES to improve the livelihood of smallholders that provide ES. 


\subsubsection{Cultural conditions}

The community living in the upland (upstream and midstream areas) are mainly trans-migrants, who have a different culture than the indigenous people living in the coastal areas, both in terms of farming practices and their working ethics. Generally, the community was also used to receiving aid from the government and the term 'project' has the connotation of a provision of 'free money'. The coinvestment scheme must be able to address these cultural issues by gradually changing community behaviour and raising its awareness towards more environmentally friendly actions, accommodating its needs, and involving it throughout the programme to ensure sustainability.

\subsubsection{Institutional and human resource conditions}

In Buol, the ES beneficiaries (or those that are being threatened by environmental degradation) are also potential ES providers, hence the inexistence of external buyers (Table 8). The palm-oil factory (plantation) could become a prominent player in supporting a co-investment scheme in Buol representing the private sector. Presently, however, the vested interests of the palm-oil company to sustainably manage the landscape need to be increased.

Further capacity building in various aspects for different types of stakeholders, such as the government and smallholders, is required in order to promote co-investment. The role of local government to facilitate stakeholders and intermediate is crucial to the success of the co-investment scheme. At the moment, we observe that the understanding and capacity of local government to intermediate, at least in the planning and monitoring/evaluation phase, is limited.

The implementation of a co-investment scheme requires smallholders to be able to contribute and get involved in the schemes. We see the potential of tree-based agriculture to improve livelihoods and the environmental condition of the landscapes, both in the watershed and the coastal area. However, the knowledge and ability of the smallholders to conduct tree-based farm management is still limited. Building the capacity of the female and male smallholders to develop and manage their tree-based farms as well as their awareness on the environmental consequences of their activities are challenges that need to be overcome in the implementation of the co-investment scheme.

\subsection{Potential co-investment schemes}

Given the challenges of PES development in Buol, a co-investment scheme in environmental stewardship (CIS) focusing on integrating natural, human, and social capital to improve the natural and financial capital of service providers is deemed to be most appropriate (van Noordwijk and Leimona, 2010).

We listed the potential co-investment schemes that can be developed in Buol given the current cultural, economic, and institutional situation. In general, the scheme focuses on restoration by planting trees in the landscape that will enhance and restore the watershed function and biodiversity. 
The co-investment schemes involve only the local community and government, as both are 'institutions' that has vested interests in managing the landscape.

To ensure sustainability, the proposed schemes in their implementation must be able to include the following:

1. The potential to increase income, such as through improving agricultural management and commodity value chains;

2. Capacity building to improve the awareness of the potential co-investors (local community and government) about sustainable landscape management; and

3. Establishment of a specific forum dedicated to monitoring and evaluating the co-investment scheme, including the provision of technical support to carry out the monitoring and evaluation on the progress of conditionality. 
Table 12. Ecosystem services provisioning and their associated providers' and beneficiaries' potential for RES scheme development in Buol district.

\begin{tabular}{|c|c|c|c|c|c|c|c|}
\hline No & $\begin{array}{l}\text { Ecosystem } \\
\text { services }\end{array}$ & Providers & Beneficiaries & Activities & Scale & Scheme & Co-benefits \\
\hline 1. & $\begin{array}{l}\text { Carbon } \\
\text { sequestration } \\
\text { through increase in } \\
\text { tree cover } \\
\text { (restoration) }\end{array}$ & Farmers & $\begin{array}{l}\text { - National and } \\
\text { global carbon } \\
\text { off-setters }\end{array}$ & $\begin{array}{l}\text { Enhancement of } \\
\text { trees in farmers' } \\
\text { private plot }\end{array}$ & $\begin{array}{ll}\text { - } & \text { Farmers } \\
\text { group } \\
\text { - } \quad \text { Community } \\
\text { land }\end{array}$ & $\begin{array}{l}\text { - Use of public funds as } \\
\text { a part of governmental } \\
\text { activities to reduce } \\
\text { emissions. } \\
\text { - Voluntary Carbon } \\
\text { Mechanism }\end{array}$ & $\begin{array}{l}\text { Enhancing livelihoods of local } \\
\text { farmers through non-timber } \\
\text { commodities, or sustainable } \\
\text { community-forest } \\
\text { management, and increase } \\
\text { their capacity to manage their } \\
\text { farms }\end{array}$ \\
\hline 2. & $\begin{array}{l}\text { Tree-planting in the } \\
\text { river bank and other } \\
\text { critical areas }\end{array}$ & Farmers & $\begin{array}{l}\text { - } \quad \text { Local } \\
\text { community } \\
\text { - } \quad \text { Local } \\
\text { government }\end{array}$ & $\begin{array}{l}\text { Tree-planting in the } \\
\text { river bank and other } \\
\text { critical areas }\end{array}$ & $\begin{array}{ll}\text { - } & \text { Individual } \\
\text { plots } \\
\text { - } & \text { Farmers } \\
\text { group } \\
\text { - } & \text { Public land }\end{array}$ & $\begin{array}{l}\text { Use of public funds as part } \\
\text { of governmental activities } \\
\text { (District, Provincial or } \\
\text { National level) }\end{array}$ & $\begin{array}{l}\text { - Maintaining water quality } \\
\text { in the river/reduce } \\
\text { sedimentation } \\
\text { - Reduce landslides and } \\
\text { erosion }\end{array}$ \\
\hline 3. & $\begin{array}{l}\text { Restoration, } \\
\text { protecting coastal } \\
\text { areas from abrasion }\end{array}$ & $\begin{array}{l}\text { Farmers/ } \\
\text { community }\end{array}$ & $\begin{array}{l}\text { - Local } \\
\text { community } \\
\text { - } \quad \text { Local } \\
\text { government }\end{array}$ & 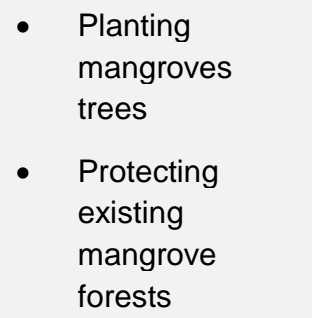 & $\begin{array}{ll}\text { - } & \text { Farmers } \\
\text { group } \\
\text { - } & \text { Public land }\end{array}$ & $\begin{array}{l}\text { Use of public funds as part } \\
\text { of governmental activities } \\
\text { (District, Provincial or } \\
\text { National level) }\end{array}$ & $\begin{array}{l}\text { Protecting the biodiversity of } \\
\text { mangrove vegetation }\end{array}$ \\
\hline
\end{tabular}




\subsection{The way forward towards co-investment of ES in Buol}

Based on the findings on the landscape's ecosystem services, smallholders' vulnerability, and challenges to develop the co-investment scheme, the Smart Tree-Invest project will apply three measures to prepare the co-investment of ES scheme in Buol.

\subsubsection{Establishment of a local multi-stakeholder forum as the intermediary}

The establishment of a local multi-stakeholder forum that consists of stakeholders from the various government departments and other actors such as NGOs, the private sector, and academia when available, is crucial to facilitate the co-investment scheme. The multi-stakeholder forum is expected to take the role as an intermediary for the upcoming co-investment scheme, where the forum will bridge the interests of the beneficiaries and smallholders, as well as monitor and evaluate the progress of coinvestment activities.

In Buol, the multi-stakeholder forum will facilitate in the watershed landscapes. We understand that the Buol district government is required by national regulation to establish a working group to coordinate the development of watersheds under their supervision. Thus, we will facilitate the establishment of a Watershed Working Group in the district as a potential intermediary in the coinvestment of ES.

\subsubsection{Building the capacity of local stakeholders to support co-investment schemes}

In view of the limited capacity of the local stakeholders (the community and the government, we will build the capacity and awareness of local government and smallholders on the co-investment of ES. The capacity building of the local government will be carried out through the multi-stakeholder forum, and is focused on improving their awareness, understanding, and capability on initiating and facilitating the development of PES/co-investment of ES.

At the village level, capacity building will be carried out in two activities through the tree-based farming management and community-based watershed management. Smart Tree-Invest will facilitate the establishment of tree-farm learning groups, for which farmers will be able to volunteer.

The smallholder tree learning group aims to increase their knowledge on tree-based farming, so they can improve their livelihoods by increasing productivity. Tree seedlings developed through their own nurseries can be used in the upcoming co-investment scheme and provide an additional source of income.

The learning group members will be facilitated and encouraged to develop their own nursery, and trained to manage their own selected tree-based commodities. The progress of the farmer group will not be determined by the project team but rather by the members themselves, depending on how eager they are to carry out the suggested activities. 
The smallholders will be involved in community-based watershed monitoring, where they are taught to monitor the condition and compile the data on the river in their village. This activity will also be a part of data gathering for the upcoming hydrological modelling research in Buol.

Community awareness raising about their condition will be conducted through village-level sharing and consultation of preliminary results. Furthermore, as another awareness raising efforts, the community will be engaged in experimental games that simulate the reality of landscape management such as the Land-use Game (Villamor et al 2013). The simulation in the game includes actors and their roles, shocks and responses, and incentives and disincentives that drive decision-making in managing the landscape.

\subsubsection{ES providers with the potential co-investors}

After the establishment of the forum and capacity building for stakeholders, the stakeholders will be facilitated to plan and develop a contractual agreement in the co-investment scheme. This will include the development of indicators for monitoring and evaluation that reflect the situation on the ground.

The lack of direct beneficiaries of ES in Buol that are capable to provide financial incentives for the ES providers requires the involvement of potential co-investors. We have identified the public funds from the national and district government as a potential funding source to finance the co-investment scheme in the watershed and coastal cluster of Buol. We also explore the possibility of engaging other private-sector players, such as oil palm plantation companies, although the opportunities are few at this stage. 


\section{Conclusion}

This paper documents the process in preparing the ground for the development of a co-investment scheme for maintaining and enhancing ecosystems services in Buol district. It also provides recommendations for the potential co-investment schemes with regards for the current biophysical, socio-economic and institutional conditions in Buol. The document intends to help local policymakers and practitioners to shape effective policy, improve the management of the landscape surrounding the community, and address the needs and perspectives of the people who depend on the landscape for their livelihoods. The proposed scheme intends to reduce the environmental threats faced by the communities while at the same time improving their livelihoods through the enhancement of existing agricultural systems and/or maintaining existing vegetation in the landscape. Given the lack of external beneficiaries in the provisioning of ecosystem services, a co-investment scheme with local government is deemed most suitable. 


\section{References}

Albrecht A., Kandji ST. 2003. Carbon sequestration in tropical agroforestry systems. Agriculture, Ecosystems and Environment 99, 15-27.

Amaruzaman S, Leimona B, Dewi S, Lusiana B, Catacutan DC and Lasco RD. 2015. Cluster Profile ClimateSmart, Tree-Based, Co-investment in Adaptation and Mitigation in Asia (SMART TREE-INVEST) Project

Amaruzaman S, Lusiana B and Leimona B. 2015. Vulnerability of smallholder farmers and their preferences on farming practices in Buol District, Indonesia. Working Paper no. 213:27 p. DOI: 10.5716/WP15724.PDF

Danielsen F, Beukema H, Burgess ND, Parish F, Bruehl CA, Donald PD, Murdiyarso D, Phalan B, Reijnders L, Struebig M, Fitzherbert EB. 2009. Biofuel plantations on forested lands: double jeopardy for biodiversity and climate. Conservation Biology 23, 348-358.

Dewi S, Khasanah N, Widayati A. 2013. Capacity-strengthening approach to vulnerability assessment (CaSAVA). In: Van Noordwijk, M., Lusiana, B., Leimona, B., Dewi, S., Wulandari, D. (Eds.), Negotiationsupport toolkit for learning landscapes. World Agroforestry Centre (ICRAF) Southeast Asia Regional Programme, Bogor, Indonesia, p. 285.

Hairiah K, Dewi S, Agus F, Velarde SJ, Ekadinata A, Rahayu S and van Noordwijk M. 2011. Measuring Carbon Stocks Across Land Use Systems: A Manual. World Agroforestry Centre (ICRAF) Southeast Asia Regional Programme, Bogor, Indonesia, p.154

Harvey C, Rakotobe Z, Rao N, Dave R, Razafimahatratra H, Rabarijohn R, Rajaofara H, MacKinnon J. 2014. Extreme vulnerability of smallholder farmers to agricultural risks and climate change in Madagascar. Philosophical Transactions of the Royal Society B, 369: 20130089.

Paramita E. 2013. New vulnerability assessment method applied in AgFor project. http://www.worldagroforestry.org/newsroom/highlights/new-vulnerability-assessment-method-appliedagfor-project. (Accessed 1 September 2016).

Rahayu S, Lusiana B, Amaruzaman S, Hendrawan DC and Pambudi S. 2015. Tree diversity and its use in Buol District, Indonesia. Working Paper 212:36 p.

Sanchez PA, Swaminathan MS. 2005. Cutting World Hunger in Half. Science 307, 357-359.

Swallow BM, Kallesoe MF, Iftikhar UA, van Noordwijk M, Bracer C, Scherr SJ, Raju KV, Poats SV, Duraiappah AK, Ochieng BO, Mallee H, Rumley R. 2009. Compensation and rewards for ecosystem services in the developing world: framing pan-tropical analysis and comparison. Ecology and Society 14(2): $2614,26-35$.

Tilman D, Cassman KG, Matson PA, Naylor R, Polasky S. 2002. Agricultural sustainability and intensive production practices. Nature 418, 671-677.

Van Noordwijk M, Leimona B. 2010. Principles for fairness and efficiency in enhancing ecosystem services in Asia: payments, compensation, or co-investment? Ecology and Society 15, 17. 
Van Noordwijk M, Lusiana B, Leimona B, Dewi S, Wulandari D. 2013. Negotiation-support toolkit for learning landscapes. World Agroforestry Centre, Bogor.

Verchot LV, van Noordwijk M, Kandji S, Tomich T, Ong C, Albrecht A, Mackensen J, Bantilan C, Anupama KV, Palm C. 2007. Climate change: linking adaptation and mitigation through agroforestry. Mitigation and Adaptation Strategies for Global Change 12, 901-918.

Wijaya CI, Rahayu S, Prasetyo A and Dwiyanti E. 2015. Dynamics of Land Use/Cover Change and Carbon Emission in Buol District, Indonesia. Working Paper no. 214:19 p. DOI: 10.5716/WP15725.PDF

Wunder S. 2008. Payments for ecosystem services and the poor: concepts and preliminary evidence. Environment and Development Economics 13, 279-297. 


\section{Appendix}

Table Appendix 1. Results from the SWOT analysis in the study sites.

A. Strengths

\begin{tabular}{|c|c|c|c|c|}
\hline Capital & Score & Upstream & Midstream & Coastal \\
\hline \multirow[t]{18}{*}{ Natural } & \multirow[t]{5}{*}{4} & Fertile Soil & Water availability & Soil type \\
\hline & & \multirow[t]{4}{*}{ Agricultural products } & Sand quarry & \multirow[t]{4}{*}{ Coconut plantation product } \\
\hline & & & Oil palm plantation & \\
\hline & & & Forest products & \\
\hline & & & Land availability & \\
\hline & \multirow[t]{4}{*}{3} & Water & Rice field & Landscape beauty \\
\hline & & Sand Quarry & Landscape beauty & Fisheries \\
\hline & & Cocoa plantation product & Fertile Soil & Available Land \\
\hline & & Available Land & Agricultural products & \\
\hline & \multirow[t]{3}{*}{2} & \multirow[t]{3}{*}{ Fisheries } & Livestock & \multirow[t]{3}{*}{ Plantation product } \\
\hline & & & Gold mine & \\
\hline & & & Forest & \\
\hline & \multirow[t]{6}{*}{1} & Oil palm plantation & & \multirow[t]{5}{*}{ Rice field } \\
\hline & & Livestock & & \\
\hline & & Landscape beauty & & \\
\hline & & Gold mine & & \\
\hline & & Forest product & & \\
\hline & & Forest & & Mines \\
\hline \multirow[t]{10}{*}{ Physical } & \multirow[t]{2}{*}{4} & \multirow[t]{2}{*}{ Health facilities } & School & \\
\hline & & & Irrigation system & \\
\hline & \multirow[t]{5}{*}{3} & School & Road access & School \\
\hline & & \multirow[t]{4}{*}{ Generator } & KTM & \multirow[t]{4}{*}{ Health facilities } \\
\hline & & & Health facilities & \\
\hline & & & Dam & \\
\hline & & & Agricultural equipment & \\
\hline & \multirow[t]{3}{*}{2} & \multirow[t]{3}{*}{ Road access } & \multirow[t]{3}{*}{ Fresh water system } & Port \\
\hline & & & & Granaries \\
\hline & & & & Communication lines \\
\hline \multirow[t]{4}{*}{ Human } & 4 & & Non-formal education & \\
\hline & 3 & People of productive age & $\begin{array}{l}\text { Agricultural } \\
\text { extensionist }\end{array}$ & Non-agricultural knowledge \\
\hline & \multirow[t]{2}{*}{2} & Non-agricultural knowledge & $\begin{array}{l}\text { Non-agricultural } \\
\text { knowledge }\end{array}$ & \multirow[t]{2}{*}{ Mining knowledge } \\
\hline & & Agricultural knowledge & Agricultural knowledge & \\
\hline \multirow[t]{3}{*}{ Financial } & \multirow[t]{2}{*}{4} & Group cash & Business capital & Credit access \\
\hline & & Cooperatives & & Cooperatives \\
\hline & 3 & & Credit access & \\
\hline
\end{tabular}




\begin{tabular}{lllll}
\hline & 2 & $\begin{array}{l}\text { Credit access } \\
\text { Food security }\end{array}$ & \\
\hline Social & 4 & Organized crop planting & Improve groups capacities \\
\cline { 2 - 5 } & & Religious group & Religious harmony & \\
\hline 2 & Health cadre & FAPOKTAN activity & \\
& Farmers group & & \\
\hline 1 & Ethnic associations & & Farmers group \\
\hline
\end{tabular}

B. Weaknesses

\begin{tabular}{|c|c|c|c|c|}
\hline Capital & Score & Upstream & Midstream & Coastal \\
\hline \multirow[t]{11}{*}{ Natural } & 4 & Pests and disease & Riverbank abrasion & Water \\
\hline & & Floods & Floods & Pest disease \\
\hline & & & & Mangrove \\
\hline & & & & Livestock \\
\hline & & & & High tide \\
\hline & 3 & Undulating topography & Undulating topography & Sand quarry \\
\hline & & Riverbank abrasion & & Riverbank abrasion \\
\hline & & & & Coastal abrasion \\
\hline & 2 & Unpredictable climate & Swamp utilization & \\
\hline & & Landslide & & \\
\hline & & Land conversion & & \\
\hline \multirow[t]{12}{*}{ Physical } & 4 & Road access & Road access & School \\
\hline & & Irrigation system & Irrigation system & Road access \\
\hline & & Fresh water system & Health facilities & Fishery equipment \\
\hline & & Electricity lines & Communication lines & \\
\hline & & Communication lines & & \\
\hline & 3 & & Sanitation & Health facilities \\
\hline & & & Fresh water system & \\
\hline & & & Electricity lines & \\
\hline & 2 & School & & \\
\hline & & Granaries & & \\
\hline & & Agricultural equipment & & \\
\hline & 1 & & & Irrigation system \\
\hline \multirow[t]{6}{*}{ Human } & 4 & Formal education & Unemployment & $\begin{array}{l}\text { Post-production } \\
\text { knowledge }\end{array}$ \\
\hline & & Agricultural knowledge & Medical personnel & Livestock knowledge \\
\hline & & & Formal education & Habit \\
\hline & & & & Fishery knowledge \\
\hline & & & & community character \\
\hline & & Agricultural extension & Agricultural knowledge & Agricultural knowledge \\
\hline
\end{tabular}




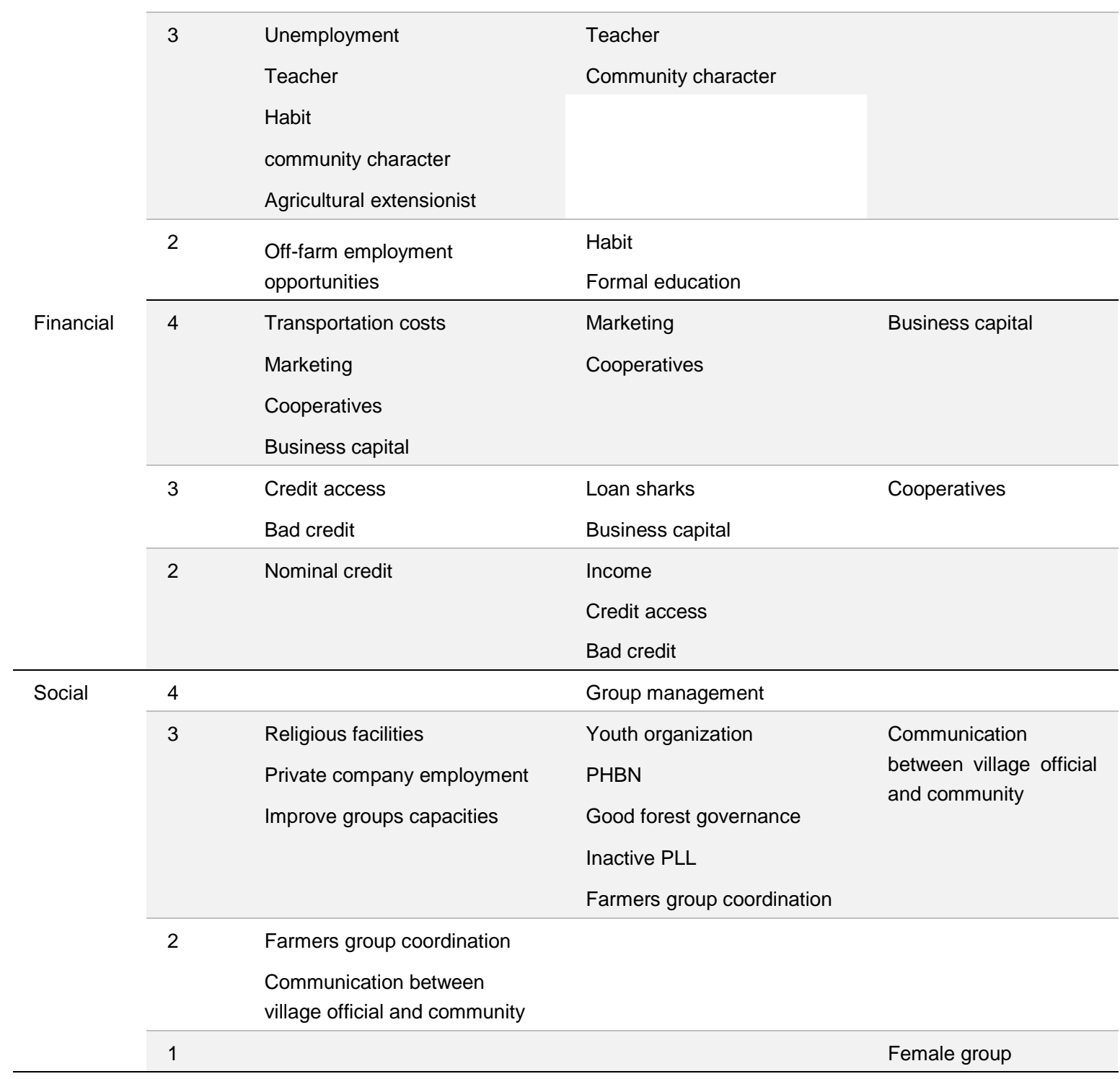

\section{Opportunities}

\begin{tabular}{|c|c|c|c|c|}
\hline Capital & Score & Upstream & Midstream & Coastal \\
\hline \multirow[t]{13}{*}{ Natural } & 4 & Nucleus estate oil palm & Nucleus estate oil palm & Developing better tree- \\
\hline & & Livestock & Tourism & based systems \\
\hline & & Agriculture development & & \\
\hline & 3 & Sand quarry & Tree farm & Tourism \\
\hline & & Forest products & Rice producer of Buol & Agriculture \\
\hline & & & Community forest scheme & development \\
\hline & & & Agriculture development & \\
\hline & 2 & Tree farm & Sand quarry & \\
\hline & & Patchouli & Fisheries & \\
\hline & & Fisheries & & \\
\hline & 1 & Tourism & & Sea product \\
\hline & & Gold mine & & Manure \\
\hline & & & & Mangrove \\
\hline
\end{tabular}




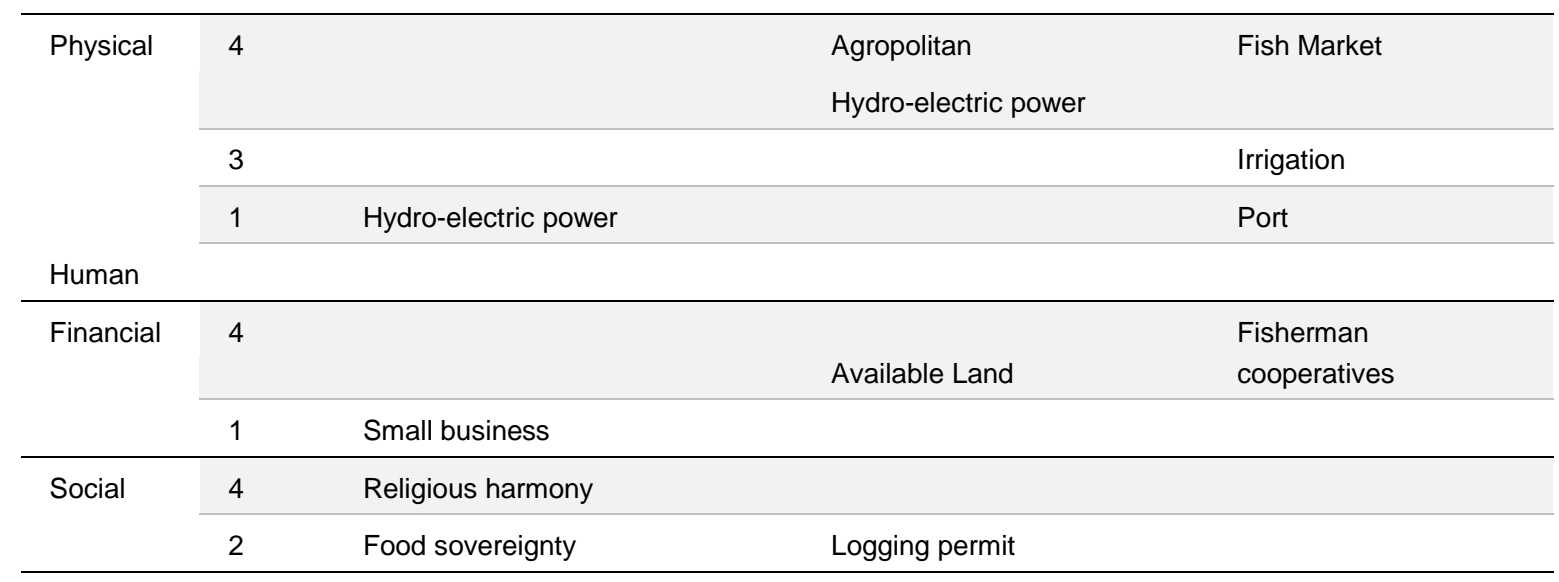

\section{Threats}

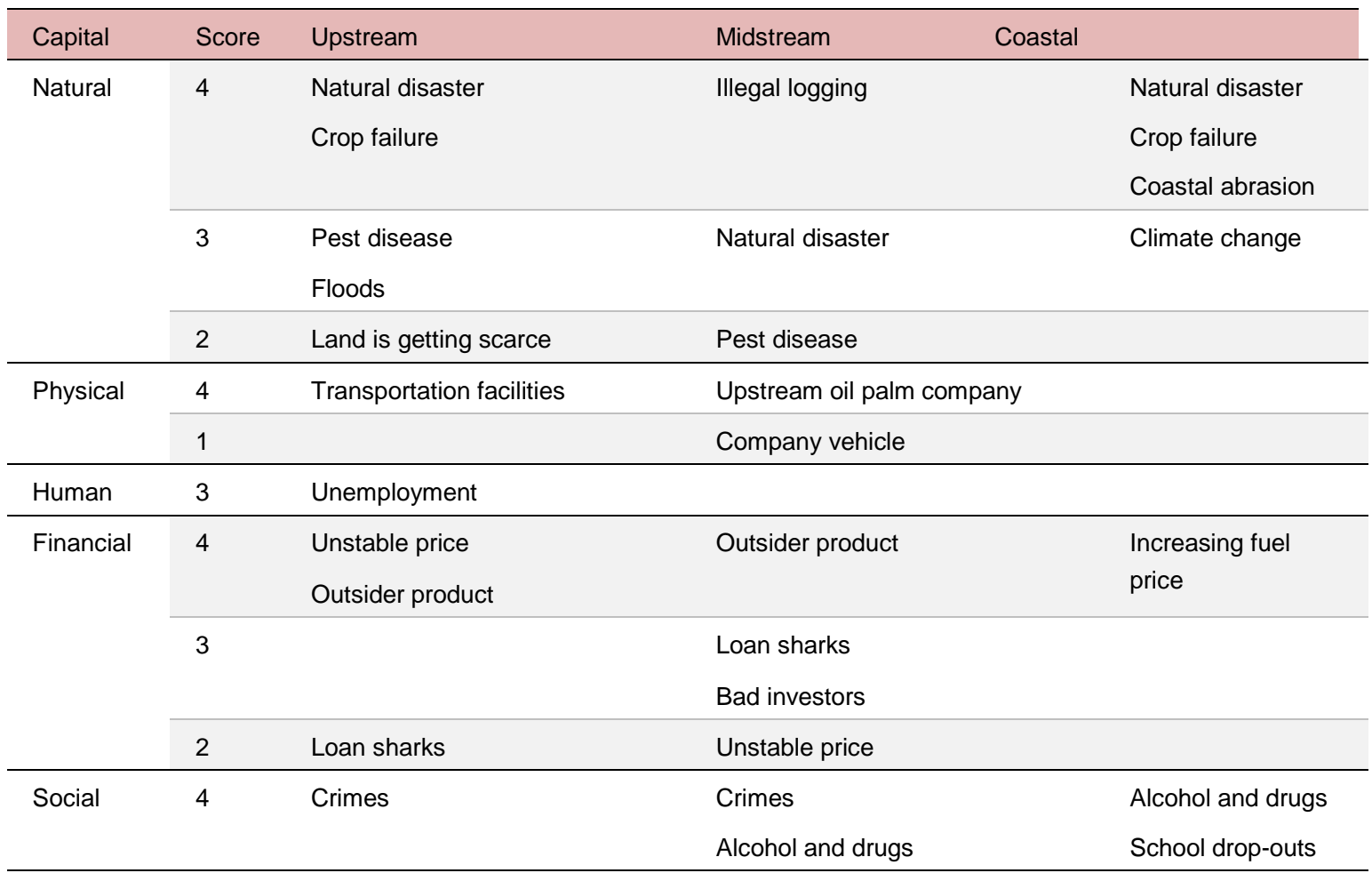


Table Appendix 3. The main environmental and economic issues in the watershed and coastal areas of Buol, based on a FGD with the local government.

\section{A. Coastal areas}

\begin{tabular}{|c|c|c|c|c|c|c|c|}
\hline Rank & Problem & Causes & Ideal condition & $\begin{array}{l}\text { Efforts to solve } \\
\text { problems }\end{array}$ & $\begin{array}{l}\text { Barriers to solve } \\
\text { problems }\end{array}$ & $\begin{array}{l}\text { Ideal effort that should have } \\
\text { been conducted }\end{array}$ & $\begin{array}{l}\text { Barriers to conduct ideal } \\
\text { efforts }\end{array}$ \\
\hline 1 & $\begin{array}{l}\text { Mangrove } \\
\text { deforestation }\end{array}$ & $\begin{array}{l}\text { - Logging for firewood } \\
\text { and building material } \\
\text { - Land conversion to } \\
\text { settlement and } \\
\text { fishpond }\end{array}$ & $\begin{array}{l}\text { - Mangrove replanting } \\
\text { - Mangrove as } \\
\text { recreation area } \\
\text { - District regulation to } \\
\text { protect mangrove } \\
\text { area }\end{array}$ & $\begin{array}{l}\text { - Raising public } \\
\text { awareness about } \\
\text { mangroves by Forestry } \\
\text { agency and } \\
\text { Environmental District } \\
\text { Agency } \\
\text { - Mangrove replanting by } \\
\text { Forestry agency and } \\
\text { Environmental District } \\
\text { Agency }\end{array}$ & $\begin{array}{l}\text { 1. Advisor's } \\
\text { operational cost to } \\
\text { go to village } \\
\text { 2. Unsustainable of } \\
\text { monitoring and } \\
\text { evaluation activity } \\
\text { 3. Lack of public } \\
\text { awareness and } \\
\text { participation } \\
\text { 4. The difficulty of } \\
\text { finding a suitable } \\
\text { seedling } \\
\text { 5. The seeds that } \\
\text { have been planted } \\
\text { are washed away } \\
\text { by the waves or } \\
\text { eaten by cattle }\end{array}$ & $\begin{array}{l}\text { 1. Develop additional value of } \\
\text { mangrove area, such as eco- } \\
\text { tourism, refined product from } \\
\text { mangroves and carp } \\
\text { aquaculture } \\
\text { 2. Clarify the regulation and the } \\
\text { zoning for mangrove } \\
\text { protection area } \\
\text { 3. Develop more detailed } \\
\text { mangrove area database at } \\
\text { the district level }\end{array}$ & $\begin{array}{l}\text { 1. Human resources lack } \\
\text { information and experience } \\
\text { related to mangrove } \\
\text { conservation } \\
\text { 2. There is no investor to } \\
\text { develop mangrove area } \\
\text { 3. Lack of community } \\
\text { awareness and } \\
\text { participation } \\
\text { 4. Advocacy of local } \\
\text { governments that are still } \\
\text { weak } \\
\text { 5. Local budget allocation for } \\
\text { environment is still low }\end{array}$ \\
\hline 2 & Coastal abrasion & $\begin{array}{l}\text { - Global warming } \\
\text { (increasing of sea level, } \\
\text { the waves are getting } \\
\text { stronger) } \\
\text { - Sand and coral mining } \\
\text { - Mangrove deforestation }\end{array}$ & $\begin{array}{l}\text { - Replanting mangroves } \\
\text { in critical areas } \\
\text { - Preventing and } \\
\text { controlling coastal } \\
\text { abrasion }\end{array}$ & $\begin{array}{l}\text { 1. Physical: build coastal } \\
\text { embankment and wave } \\
\text { breaker (from BPBD and } \\
\text { PU incidental budget) } \\
\text { 2. Replanting mangroves } \\
\text { 3. Relocating settlements } \\
\text { where the abrasion } \\
\text { occurs often (by social } \\
\text { agency and spatial } \\
\text { planning and housing } \\
\text { agency) } \\
\text { 4. Restriction of sand } \\
\text { mining (Regent Circular } \\
\text { letter, 2013) }\end{array}$ & $\begin{array}{l}\text { 1. Limited budget } \\
\text { 2. Refers to issue } \\
\text { number } 1 \\
\text { 3. Local communities } \\
\text { are reluctant to be } \\
\text { relocated } \\
\text { 4. There is no } \\
\text { alternative income } \\
\text { for sand miners }\end{array}$ & $\begin{array}{l}\text { 1. Converting sand mining area } \\
\text { into tourism zones } \\
\text { 2. Encourage sand miners to } \\
\text { become fishermen } \\
\text { 3. Designate specific areas for } \\
\text { sand mining at Buol district } \\
\text { 4. Build offshore island/rock to } \\
\text { break waves } \\
\text { 5. Increase coral reefs for home of } \\
\text { fish, which also increases } \\
\text { economic benefit }\end{array}$ & $\begin{array}{l}\text { 1. Community desires to } \\
\text { change its livelihood in the } \\
\text { coastal area } \\
\text { 2. Budget for ideal effort } \\
\text { number } 2-5 \\
\text { 3. RDTR is arranged but has } \\
\text { not been legalized by DPRD }\end{array}$ \\
\hline
\end{tabular}




\begin{tabular}{|c|c|c|c|c|c|c|c|c|c|}
\hline 3 & Poverty & $\begin{array}{l}\text { 1. Quality of human } \\
\text { resources is low } \\
\text { (attitudes, motivation, } \\
\text { skills) } \\
\text { 2. Low income } \\
\text { 3. Local communities } \\
\text { have limited access to } \\
\text { capital } \\
\text { 4. Old equipment for } \\
\text { farming and fishery } \\
\text { 5. Fishing has become } \\
\text { more difficult because } \\
\text { the location is getting } \\
\text { tougher to get to } \\
\text { 6. Fishery institutions are } \\
\text { weaker than farming } \\
\text { institutions } \\
\text { 7. Local communities do } \\
\text { not focus on one } \\
\text { commodity (they are } \\
\text { farmers, fishermen and } \\
\text { also workers) } \\
\text { 8. Having a large family } \\
\text { 9. Women's role in family } \\
\text { finance is limited } \\
\text { 10. Old coconut plantation } \\
\text { in coastal area }\end{array}$ & $\begin{array}{l}1 . \\
2 . \\
3 . \\
4 . \\
5 . \\
6 . \\
7 . \\
8 .\end{array}$ & $\begin{array}{l}\text { Having good- } \\
\text { quality of human } \\
\text { resources } \\
\text { Local community } \\
\text { has high income } \\
\text { Good spatial } \\
\text { planning for } \\
\text { settlements } \\
\text { Having modern } \\
\text { fishing equipment } \\
\text { Local communities } \\
\text { focus on one } \\
\text { commodity } \\
\text { Having women } \\
\text { empowerment and } \\
\text { family } \\
\text { KB } \\
\text { Replanting old } \\
\text { coconut plantations } \\
\text { in coastal areas }\end{array}$ & $\begin{array}{l}1 . \\
2 . \\
3 . \\
4 . \\
5 .\end{array}$ & $\begin{array}{l}\text { Community } \\
\text { empowerment (by } \\
\text { BPMD) } \\
\text { Provide fishing } \\
\text { equipment (by Marine } \\
\text { and Fisheries agency) } \\
\text { Supporting business } \\
\text { capital (fishery-PUMP, } \\
\text { agriculture-PUAP, by } \\
\text { Marine and fisheries } \\
\text { agency, agriculture } \\
\text { agency, PNPM) } \\
\text { Training for fishery } \\
\text { processing (by BPMD) } \\
\text { Establishing school of } \\
\text { fishery at high school } \\
\text { level }\end{array}$ & $\begin{array}{l}\text { - Budget allocation for } \\
\text { community } \\
\text { empowerment is still } \\
\text { limited } \\
\text { - Lack of programme } \\
\text { coordination and } \\
\text { integration among } \\
\text { sectors in coastal } \\
\text { areas } \\
\text { - Human resource and } \\
\text { space for women is } \\
\text { limited } \\
\text { (empowerment } \\
\text { activity is dominated } \\
\text { by men) }\end{array}$ & $\begin{array}{l}\text { - Previous optimization efforts } \\
\text { - Provide scholarships from the } \\
\text { Faculty of Marine and } \\
\text { Fisheries for children who live } \\
\text { in coastal areas }\end{array}$ & $\begin{array}{l}\text { Local government has } \\
\text { limited budget } \\
\text { Human resources and } \\
\text { motivation of local } \\
\text { communities is low }\end{array}$ \\
\hline
\end{tabular}




\section{B. Watershed areas}

\begin{tabular}{|c|c|c|c|c|c|c|c|c|c|}
\hline No & Problems & & Causes & Ideal condition & & Previous efforts & Barriers & $\begin{array}{l}\text { Ideal efforts that } \\
\text { should have been } \\
\text { done) }\end{array}$ & $\begin{array}{l}\text { Barriers to doing } \\
\text { ideal efforts }\end{array}$ \\
\hline 1 & $\begin{array}{l}\text { Land use/cover } \\
\text { change }\end{array}$ & $\begin{array}{l}1 . \\
2 . \\
2 .\end{array}$ & $\begin{array}{l}\text { Inadequate } \\
\text { irrigation } \\
\text { systems, so that } \\
\text { a lot of seasonal } \\
\text { crop areas are } \\
\text { converted into } \\
\text { plantations } \\
\text { The issuance of } \\
\text { concessions or } \\
\text { the changes of } \\
\text { regional status } \\
\text { Decreasing of } \\
\text { productive land } \\
\text { because of } \\
\text { population growth } \\
\text { Large-scale land } \\
\text { clearing because } \\
\text { of investment }\end{array}$ & $\begin{array}{l}\text { Land use } \\
\text { according to its } \\
\text { suitability, } \\
\text { allocation, and } \\
\text { carrying capacity }\end{array}$ & 3. & $\begin{array}{l}\text { KLHS (Strategic } \\
\text { environmental } \\
\text { assessment/Kajian } \\
\text { Lingkungan Hidup Strategis) } \\
\text { (by BLH, 2013) } \\
\text { Arrange RTRW (by Spatial } \\
\text { planning agency, 2012) } \\
\text { Arrange commodity zoning } \\
\text { (by agriculture agency, 2005) } \\
\text { Moratorium for land clearing } \\
\text { for oil palm (by regent, 2012) } \\
\text { BKPRD (Badan Koordinasi } \\
\text { Penataan Ruang } \\
\text { Daerah/Coordinating Bureau } \\
\text { for Land Use } \\
\text { Planning)/Provincial } \\
\text { Development planning } \\
\text { Bureau/2013 } \\
\text { RPJMD (medium-term local } \\
\text { development plan/Rencana } \\
\text { Pembangunan Jangka } \\
\text { Menengah Daerah) (The } \\
\text { result from RTRW. Local } \\
\text { government together with } \\
\text { experts) }\end{array}$ & $\begin{array}{l}\text { 1. Lack of coordination } \\
\text { among sectors } \\
\text { 2. Human resources } \\
\text { does not understand } \\
\text { documents that have } \\
\text { been prepared } \\
\text { 3. The budget leads to } \\
\text { certain } \\
\text { allocation/there is } \\
\text { budget limitation } \\
\text { 4. There is no clear } \\
\text { agreement about the } \\
\text { boundaries }\end{array}$ & $\begin{array}{l}\text { 1. Inviting investors for } \\
\text { better } \\
\text { implementation } \\
\text { 2. Wider socialization of } \\
\text { plans and efforts } \\
\text { 3. P3 together with } \\
\text { private company } \\
\text { provide local } \\
\text { infrastructure } \\
\text { 4. Make controlling } \\
\text { function stronger } \\
\text { 5. Strengthening } \\
\text { control function to } \\
\text { optimize the actual } \\
\text { effort }\end{array}$ & $\begin{array}{l}\text { 1. Lack of } \\
\text { stakeholder } \\
\text { commitment (the } \\
\text { main barriers) } \\
\text { 2. Lack of rewards } \\
\text { and punishments } \\
\text { 3. Lack of } \\
\text { supervision }\end{array}$ \\
\hline 2 & $\begin{array}{l}\text { Sedimentation, } \\
\text { river abrasion } \\
\text { and erosion }\end{array}$ & 2. & $\begin{array}{l}\text { Illegal logging, } \\
\text { that will increase } \\
\text { runoff and } \\
\text { sedimentation } \\
\text { Shifting } \\
\text { cultivation }\end{array}$ & $\begin{array}{l}\text { Decreasing } \\
\text { sedimentation rate } \\
\text { to set threshold } \\
\text { value }\end{array}$ & 1. & $\begin{array}{l}\text { Land and forest rehabilitation } \\
\text { (by Forestry agency, 2000- } \\
\text { now) } \\
\text { Make master plan for land } \\
\text { and forest rehabilitation (by }\end{array}$ & $\begin{array}{l}\text { 1. Budget limitation } \\
\text { 2. Lack of stakeholder } \\
\text { commitment } \\
\text { 3. Lack of human } \\
\text { resources and local }\end{array}$ & 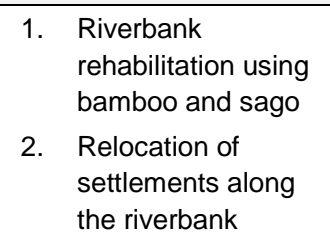 & $\begin{array}{l}\text { 1. Lack of } \\
\text { stakeholder } \\
\text { commitment (the } \\
\text { main barrier) } \\
\text { 2. Lack of rewards } \\
\text { and punishments }\end{array}$ \\
\hline
\end{tabular}




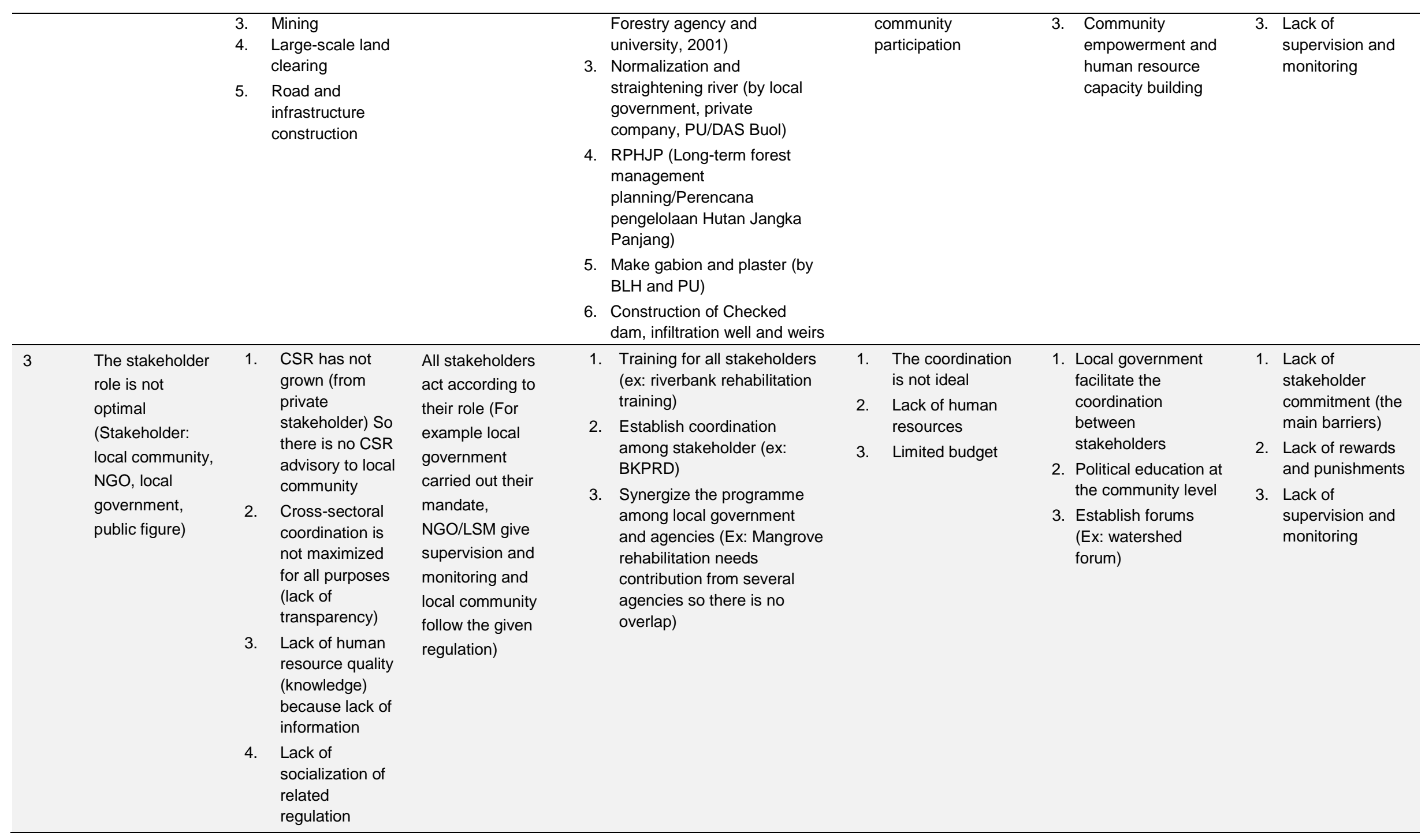




\section{WORKING PAPERS WITH DOIS}

2005

1. Agroforestry in the drylands of eastern Africa: a call to action

2. Biodiversity conservation through agroforestry: managing tree species diversity within a network of community-based, nongovernmental, governmental and research organizations in western Kenya.

3. Invasion of prosopis juliflora and local livelihoods: Case study from the Lake Baringo area of Kenya

4. Leadership for change in farmers organizations: Training report: Ridar Hotel, Kampala, 29th March to 2nd April 2005.

5. Domestication des espèces agroforestières au Sahel : situation actuelle et perspectives

6. Relevé des données de biodiversité ligneuse: Manuel du projet biodiversité des parcs agroforestiers au Sahel

7. Improved land management in the Lake Victoria Basin: TransVic Project's draft report.

8. Livelihood capital, strategies and outcomes in the Taita hills of Kenya

9. Les espèces ligneuses et leurs usages: Les préférences des paysans dans le Cercle de Ségou, au Mali

10. La biodiversité des espèces ligneuses: Diversité arborée et unités de gestion du terroir dans le Cercle de Ségou, au Mali

\section{6}

11. Bird diversity and land use on the slopes of Mt. Kilimanjaro and the adjacent plains, Tanzania

12. Water, women and local social organization in the Western Kenya Highlands

13. Highlights of ongoing research of the World Agroforestry Centre in Indonesia

14. Prospects of adoption of tree-based systems in a rural landscape and its likely impacts on carbon stocks and farmers' welfare: The FALLOW Model Application in Muara Sungkai, Lampung, Sumatra, in a 'Clean Development Mechanism' context

15. Equipping integrated natural resource managers for healthy Agroforestry landscapes.

17. Agro-biodiversity and CGIAR tree and forest science: approaches and examples from Sumatra.

18. Improving land management in eastern and southern Africa: A review of policies.

19. Farm and household economic study of Kecamatan Nanggung, Kabupaten Bogor, Indonesia: A socio-economic base line study of Agroforestry innovations and livelihood enhancement.

20. Lessons from eastern Africa's unsustainable charcoal business.

21. Evolution of RELMA's approaches to land management: Lessons from two decades of research and development in eastern and southern Africa

22. Participatory watershed management: Lessons from RELMA's work with farmers in eastern Africa.

23. Strengthening farmers' organizations: The experience of RELMA and ULAMP.

24. Promoting rainwater harvesting in eastern and southern Africa.

25. The role of livestock in integrated land management.

26. Status of carbon sequestration projects in Africa: Potential benefits and challenges to scaling up. 
27. Social and Environmental Trade-Offs in Tree Species Selection: A Methodology for Identifying Niche Incompatibilities in Agroforestry [Appears as AHI Working Paper no. 9]

28. Managing tradeoffs in agroforestry: From conflict to collaboration in natural resource management. [Appears as AHI Working Paper no. 10]

29. Essai d'analyse de la prise en compte des systemes agroforestiers pa les legislations forestieres au Sahel: Cas du Burkina Faso, du Mali, du Niger et du Senegal.

30. Etat de la recherche agroforestière au Rwanda etude bibliographique, période 1987-2003

2007

31. Science and technological innovations for improving soil fertility and management in Africa: A report for NEPAD's Science and Technology Forum.

32. Compensation and rewards for environmental services.

33. Latin American regional workshop report compensation.

34. Asia regional workshop on compensation ecosystem services.

35. Report of African regional workshop on compensation ecosystem services.

36. Exploring the inter-linkages among and between compensation and rewards for ecosystem services CRES and human well-being

37. Criteria and indicators for environmental service compensation and reward mechanisms: realistic, voluntary, conditional and pro-poor

38. The conditions for effective mechanisms of compensation and rewards for environmental services.

39. Organization and governance for fostering Pro-Poor Compensation for Environmental Services.

40. How important are different types of compensation and reward mechanisms shaping poverty and ecosystem services across Africa, Asia \& Latin America over the Next two decades?

41. Risk mitigation in contract farming: The case of poultry, cotton, woodfuel and cereals in East Africa.

42. The RELMA savings and credit experiences: Sowing the seed of sustainability

43. Yatich J., Policy and institutional context for NRM in Kenya: Challenges and opportunities for Landcare.

44. Nina-Nina Adoung Nasional di So! Field test of rapid land tenure assessment (RATA) in the Batang Toru Watershed, North Sumatera.

45. Is Hutan Tanaman Rakyat a new paradigm in community based tree planting in Indonesia?

46. Socio-Economic aspects of brackish water aquaculture (Tambak) production in Nanggroe Aceh Darrusalam.

47. Farmer livelihoods in the humid forest and moist savannah zones of Cameroon.

48. Domestication, genre et vulnérabilité : Participation des femmes, des Jeunes et des catégories les plus pauvres à la domestication des arbres agroforestiers au Cameroun.

49. Land tenure and management in the districts around Mt Elgon: An assessment presented to the Mt Elgon ecosystem conservation programme.

50. The production and marketing of leaf meal from fodder shrubs in Tanga, Tanzania: A pro-poor enterprise for improving livestock productivity.

51. Buyers Perspective on Environmental Services (ES) and Commoditization as an approach to liberate ES markets in the Philippines. 
52. Towards Towards community-driven conservation in southwest China: Reconciling state and local perceptions.

53. Biofuels in China: An Analysis of the Opportunities and Challenges of Jatropha curcas in Southwest China.

54. Jatropha curcas biodiesel production in Kenya: Economics and potential value chain development for smallholder farmers

55. Livelihoods and Forest Resources in Aceh and Nias for a Sustainable Forest Resource Management and Economic Progress

56. Agroforestry on the interface of Orangutan Conservation and Sustainable Livelihoods in Batang Toru, North Sumatra.

2008

57. Assessing Hydrological Situation of Kapuas Hulu Basin, Kapuas Hulu Regency, West Kalimantan.

58. Assessing the Hydrological Situation of Talau Watershed, Belu Regency, East Nusa Tenggara.

59. Kajian Kondisi Hidrologis DAS Talau, Kabupaten Belu, Nusa Tenggara Timur.

60. Kajian Kondisi Hidrologis DAS Kapuas Hulu, Kabupaten Kapuas Hulu, Kalimantan Barat.

61. Lessons learned from community capacity building activities to support agroforest as sustainable economic alternatives in Batang Toru orang utan habitat conservation program (Martini, Endri et al.)

62. Mainstreaming Climate Change in the Philippines.

63. A Conjoint Analysis of Farmer Preferences for Community Forestry Contracts in the Sumber Jaya Watershed, Indonesia.

64. The highlands: a shared water tower in a changing climate and changing Asia

65. Eco-Certification: Can It Deliver Conservation and Development in the Tropics.

66. Designing ecological and biodiversity sampling strategies. Towards mainstreaming climate change in grassland management.

67. Towards mainstreaming climate change in grassland management policies and practices on the Tibetan Plateau

68. An Assessment of the Potential for Carbon Finance in Rangelands

69 ECA Trade-offs Among Ecosystem Services in the Lake Victoria Basin.

69. The last remnants of mega biodiversity in West Java and Banten: an in-depth exploration of RaTA (Rapid Land Tenure Assessment) in Mount Halimun-Salak National Park Indonesia

70. Le business plan d'une petite entreprise rurale de production et de commercialisation des plants des arbres locaux. Cas de quatre pépinières rurales au Cameroun.

71. Les unités de transformation des produits forestiers non ligneux alimentaires au Cameroun. Diagnostic technique et stratégie de développement Honoré Tabuna et Ingratia Kayitavu.

72. Les exportateurs camerounais de safou (Dacryodes edulis) sur le marché sous régional et international. Profil, fonctionnement et stratégies de développement.

73. Impact of the Southeast Asian Network for Agroforestry Education (SEANAFE) on agroforestry education capacity.

74. Setting landscape conservation targets and promoting them through compatible land use in the Philippines.

75. Review of methods for researching multistrata systems. 
76. Study on economical viability of Jatropha curcas L. plantations in Northern Tanzania assessing farmers' prospects via cost-benefit analysis

77. Cooperation in Agroforestry between Ministry of Forestry of Indonesia and International Center for Research in Agroforestry

78. "China's bioenergy future. an analysis through the Lens if Yunnan Province

79. Land tenure and agricultural productivity in Africa: A comparative analysis of the economics literature and recent policy strategies and reforms

80. Boundary organizations, objects and agents: linking knowledge with action in Agroforestry watersheds

81. Reducing emissions from deforestation and forest degradation (REDD) in Indonesia: options and challenges for fair and efficient payment distribution mechanisms

2009

82. Mainstreaming climate change into agricultural education: challenges and perspectives

83. Challenging conventional mindsets and disconnects in conservation: the emerging role of ecoagriculture in Kenya's landscape mosaics

84. Lesson learned RATA garut dan bengkunat: suatu upaya membedah kebijakan pelepasan kawasan hutan dan redistribusi tanah bekas kawasan hutan

85. The emergence of forest land redistribution in Indonesia

86. Commercial opportunities for fruit in Malawi

87. Status of fruit production processing and marketing in Malawi

88. Fraud in tree science

89. Trees on farm: analysis of global extent and geographical patterns of agroforestry

90. The springs of Nyando: water, social organization and livelihoods in Western Kenya

91. Building capacity toward region-wide curriculum and teaching materials development in agroforestry education in Southeast Asia

92. Overview of biomass energy technology in rural Yunnan (Chinese - English abstract)

93. A pro-growth pathway for reducing net GHG emissions in China

94. Analysis of local livelihoods from past to present in the central Kalimantan Ex-Mega Rice Project area

95. Constraints and options to enhancing production of high quality feeds in dairy production in Kenya, Uganda and Rwanda

2010

96. Agroforestry education in the Philippines: status report from the Southeast Asian Network for Agroforestry Education (SEANAFE)

97. Economic viability of Jatropha curcas L. plantations in Northern Tanzania- assessing farmers' prospects via cost-benefit analysis.

98. Hot spot of emission and confusion: land tenure insecurity, contested policies and competing claims in the central Kalimantan Ex-Mega Rice Project area

99. Agroforestry competences and human resources needs in the Philippines

100. CES/COS/CIS paradigms for compensation and rewards to enhance environmental Services 
101. Case study approach to region-wide curriculum and teaching materials development in agroforestry education in Southeast Asia

102. Stewardship agreement to reduce emissions from deforestation and degradation (REDD): Lubuk Beringin's Hutan Desa as the first village forest in Indonesia

103. Landscape dynamics over time and space from ecological perspective

104. Komoditisasi atau koinvestasi jasa lingkungan: skema imbal jasa lingkungan program peduli sungai di DAS Way Besai, Lampung, Indonesia

105. Improving smallholders' rubber quality in Lubuk Beringin, Bungo district, Jambi province, Indonesia: an initial analysis of the financial and social benefits

106. Rapid Carbon Stock Appraisal (RACSA) in Kalahan, Nueva Vizcaya, Philippines

107. Tree domestication by ICRAF and partners in the Peruvian Amazon: lessons learned and future prospects in the domain of the Amazon Initiative eco-regional program

108. Memorias del Taller Nacional: "Iniciativas para Reducir la Deforestación en la region Andino Amazónica", 09 de Abril del 2010. Proyecto REALU Peru

109. Percepciones sobre la Equidad y Eficiencia en la cadena de valor de REDD en Perú -Reporte de Talleres en Ucayali, San Martín y Loreto, 2009. Proyecto REALU-Perú.

110. Reducción de emisiones de todos los Usos del Suelo. Reporte del Proyecto REALU Perú Fase 1

111. Programa Alternativas a la Tumba-y-Quema (ASB) en el Perú. Informe Resumen y Síntesis de la Fase II. 2da. versión revisada

112. Estudio de las cadenas de abastecimiento de germoplasma forestal en la amazonía Boliviana

113. Biodiesel in the Amazon

114. Estudio de mercado de semillas forestales en la amazonía Colombiana

115. Estudio de las cadenas de abastecimiento de germoplasma forestal en Ecuador http://dx.doi.org10.5716/WP10340.PDF

116. How can systems thinking, social capital and social network analysis help programs achieve impact at scale?

117. Energy policies, forests and local communities in the Ucayali Region, Peruvian Amazon

118. NTFPs as a Source of Livelihood Diversification for Local Communities in the Batang Toru Orangutan Conservation Program

119. Studi Biodiversitas: Apakah agroforestry mampu mengkonservasi keanekaragaman hayati di DAS Konto?

120. Estimasi Karbon Tersimpan di Lahan-lahan Pertanian di DAS Konto, Jawa Timur

121. Implementasi Kaji Cepat Hidrologi (RHA) di Hulu DAS Brantas, Jawa Timur. http://dx.doi.org/10.5716/WP10338.PDF

122. Kaji Cepat Hidrologi di Daerah Aliran Sungai Krueng Peusangan, NAD,Sumatra http://dx.doi.org/10.5716/WP10337.PDF

123. A Study of Rapid Hydrological Appraisal in the Krueng Peusangan Watershed, NAD, Sumatra. http://dx.doi.org/10.5716/WP10339.PDF

2011

124. An Assessment of farm timber value chains in Mt Kenya area, Kenya

125. A Comparative financial analysis of current land use systems and implications for the adoption of improved agroforestry in the East Usambaras, Tanzania

126. Agricultural monitoring and evaluation systems 
127. Challenges and opportunities for collaborative landscape governance in the East Usambara Mountains, Tanzania

128. Transforming Knowledge to Enhance Integrated Natural Resource Management Research, Development and Advocacy in the Highlands of Eastern Africa http://dx.doi.org/10.5716/WP11084.PDF

129. Carbon-forestry projects in the Philippines: potential and challenges The Mt Kitanglad Range forest-carbon development http://dx.doi.org10.5716/WP11054.PDF

130. Carbon forestry projects in the Philippines: potential and challenges. The Arakan Forest Corridor forest-carbon project. http://dx.doi.org10.5716/WP11055.PDF

131. Carbon-forestry projects in the Philippines: potential and challenges. The Laguna Lake Development Authority's forest-carbon development project. http://dx.doi.org/10.5716/WP11056.PDF

132. Carbon-forestry projects in the Philippines: potential and challenges. The Quirino forest-carbon development project in Sierra Madre Biodiversity Corridor http://dx.doi.org10.5716/WP11057.PDF

133. Carbon-forestry projects in the Philippines: potential and challenges. The Ikalahan Ancestral Domain forest-carbon development http://dx.doi.org10.5716/WP11058.PDF

134. The Importance of Local Traditional Institutions in the Management of Natural Resources in the Highlands of Eastern Africa. http://dx.doi.org/10.5716/WP11085.PDF

135. Socio-economic assessment of irrigation pilot projects in Rwanda. http://dx.doi.org/10.5716/WP11086.PDF

136. Performance of three rambutan varieties (Nephelium lappaceum L.) on various nursery media. http://dx.doi.org/10.5716/WP11232.PDF

137. Climate change adaptation and social protection in agroforestry systems: enhancing adaptive capacity and minimizing risk of drought in Zambia and Honduras http://dx.doi.org/10.5716/WP11269.PDF

138. Does value chain development contribute to rural poverty reduction? Evidence of asset building by smallholder coffee producers in Nicaragua http://dx.doi.org/10.5716/WP11271.PDF

139. Potential for biofuel feedstock in Kenya. http://dx.doi.org/10.5716/WP11272.PDF

140. Impact of fertilizer trees on maize production and food security in six districts of Malawi. http://dx.doi.org/10.5716/WP11281.PDF

2012

141. Fortalecimiento de capacidades para la gestión del Santuario Nacional Pampa Hermosa: Construyendo las bases para un manejo adaptativo para el desarrollo local. Memorias del Proyecto. http://dx.doi.org/10.5716/WP12005.PDF

142. Understanding rural institutional strengthening: A cross-level policy and institutional framework for sustainable development in Kenya http://dx.doi.org/10.5716/WP12012.PDF

143. Climate change vulnerability of agroforestry http://dx.doi.org/10.5716/WP16722.PDF

144. Rapid assesment of the inner Niger delta of Mali http://dx.doi.org/10.5716/WP12021.PDF

145. Designing an incentive program to reduce on-farm deforestationin the East Usambara Mountains, Tanzania http://dx.doi.org/10.5716/WP12048.PDF

146. Extent of adoption of conservation agriculture and agroforestry in Africa: the case of Tanzania, Kenya, Ghana, and Zambia http://dx.doi.org/10.5716/WP12049.PDF 
147. Policy incentives for scaling up conservation agriculture with trees in Africa: the case of Tanzania, Kenya, Ghana and Zambia http://dx.doi.org/10.5716/WP12050.PDF

148. Commoditized or co-invested environmental services? Rewards for environmental services scheme: River Care program Way Besai watershed, Lampung, Indonesia.

http://dx.doi.org/10.5716/WP12051.PDF

149. Assessment of the headwaters of the Blue Nile in Ethiopia. http://dx.doi.org/10.5716/WP12160.PDF

150. Assessment of the uThukela Watershed, Kwazaulu. http://dx.doi.org/10.5716/WP12161.PDF

151. Assessment of the Oum Zessar Watershed of Tunisia. http://dx.doi.org/10.5716/WP12162.PDF

152. Assessment of the Ruwenzori Mountains in Uganda. http://dx.doi.org/10.5716/WP12163.PDF

153. History of agroforestry research and development in Viet Nam. Analysis of research opportunities and gaps. http://dx.doi.org/10.5716/WP12052.PDF

154. REDD+ in Indonesia: a Historical Perspective. http://dx.doi.org/10.5716/WP12053.PDF

155. Agroforestry and Forestry in Sulawesi series: Livelihood strategies and land use system dynamics in South Sulawesi http://dx.doi.org/10.5716/WP12054.PDF

156. Agroforestry and Forestry in Sulawesi series: Livelihood strategies and land use system dynamics in Southeast Sulawesi. http://dx.doi.org/10.5716/WP12055.PDF

157. Agroforestry and Forestry in Sulawesi series: Profitability and land-use systems in South and Southeast Sulawesi. http://dx.doi.org/10.5716/WP12056.PDF

158. Agroforestry and Forestry in Sulawesi series: Gender, livelihoods and land in South and Southeast Sulawesi http://dx.doi.org/10.5716/WP12057.PDF

159. Agroforestry and Forestry in Sulawesi series: Agroforestry extension needs at the community level in AgFor project sites in South and Southeast Sulawesi, Indonesia. http://dx.doi.org/10.5716/WP12058.PDF

160. Agroforestry and Forestry in Sulawesi series: Rapid market appraisal of agricultural, plantation and forestry commodities in South and Southeast Sulawesi.

http://dx.doi.org/10.5716/WP12059.PDF

2013

161. Diagnosis of farming systems in the Agroforestry for Livelihoods of Smallholder farmers in Northwestern Viet Nam project http://dx.doi.org/10.5716/WP13033.PDF

162. Ecosystem vulnerability to climate change: a literature review. http://dx.doi.org/10.5716/WP13034.PDF

163. Local capacity for implementing payments for environmental services schemes: lessons from the RUPES project in northeastern Viet Nam http://dx.doi.org/10.5716/WP13046.PDF

164. Seri Agroforestri dan Kehutanan di Sulawesi: Agroforestry dan Kehutanan di Sulawesi: Strategi mata pencaharian dan dinamika sistem penggunaan lahan di Sulawesi Selatan http://dx.doi.org/10.5716/WP13040.PDF

165. Seri Agroforestri dan Kehutanan di Sulawesi: Mata pencaharian dan dinamika sistem penggunaan lahan di Sulawesi Tenggara http://dx.doi.org/10.5716/WP13041.PDF

166. Seri Agroforestri dan Kehutanan di Sulawesi: Profitabilitas sistem penggunaan lahan di Sulawesi Selatan dan Sulawesi Tenggara http://dx.doi.org/10.5716/WP13042.PDF

167. Seri Agroforestri dan Kehutanan di Sulawesi: Gender, mata pencarian dan lahan di Sulawesi Selatan dan Sulawesi Tenggara http://dx.doi.org/10.5716/WP13043.PDF 
168. Seri Agroforestri dan Kehutanan di Sulawesi: Kebutuhan penyuluhan agroforestri pada tingkat masyarakat di lokasi proyek AgFor di Sulawesi Selatan dan Tenggara, Indonesia. http://dx.doi.org/10.5716/WP13044.PDF

169. Seri Agroforestri dan Kehutanan di Sulawesi: Laporan hasil penilaian cepat untuk komoditas pertanian, perkebunan dan kehutanan di Sulawesi Selatan dan Tenggara http://dx.doi.org/10.5716/WP13045.PDF

170. Agroforestry, food and nutritional security http://dx.doi.org/10.5716/WP13054.PDF

171. Stakeholder Preferences over Rewards for Ecosystem Services: Implications for a REDD+ Benefit Distribution System in Viet Nam http://dx.doi.org/10.5716/WP13057.PDF

172. Payments for ecosystem services schemes: project-level insights on benefits for ecosystems and the rural poor http://dx.doi.org/10.5716/WP13001.PDF

173. Good practices for smallholder teak plantations: keys to success http://dx.doi.org/10.5716/WP13246.PDF

174. Market analysis of selected agroforestry products in the Vision for Change Project intervention Zone, Côte d'Ivoire http://dx.doi.org/10.5716/WP13249.PDF

175. Rattan futures in Katingan: why do smallholders abandon or keep their gardens in Indonesia's 'rattan district'? http://dx.doi.org/10.5716/WP13251.PDF

176. Management along a gradient: the case of Southeast Sulawesi's cacao production landscapes http://dx.doi.org/10.5716/WP13265.PDF

2014

177. Are trees buffering ecosystems and livelihoods in agricultural landscapes of the Lower Mekong Basin? Consequences for climate-change adaptation. http://dx.doi.org/10.5716/WP14047.PDF

178. Agroforestry, livestock, fodder production and climate change adaptation and mitigation in East Africa: issues and options. http://dx.doi.org/10.5716/WP14050.PDF

179. Trees on farms: an update and reanalysis of agroforestry's global extent and socio-ecological characteristics. http://dx.doi.org/10.5716/WP14064.PDF

180. Beyond reforestation: an assessment of Vietnam's REDD+ readiness. http://dx.doi.org/10.5716/WP14097.PDF

181. Farmer-to-farmer extension in Kenya: the perspectives of organizations using the approach. http://dx.doi.org/10.5716/WP14380.PDF

182. Farmer-to-farmer extension in Cameroon: a survey of extension organizations. http://dx.doi.org/10.5716/WP14383.PDF

183. Farmer-to-farmer extension approach in Malawi: a survey of organizations: a survey of organizations http://dx.doi.org/10.5716/WP14391.PDF

184. Seri Agroforestri dan Kehutanan di Sulawesi: Kuantifikasi jasa lingkungan air dan karbon pola agroforestri pada hutan rakyat di wilayah sungai Jeneberang

185. Options for Climate-Smart Agriculture at Kaptumo Site in Kenyahttp://dx.doi.org/10.5716/WP14394.PDF

2015

186. Agroforestry for Landscape Restoration and Livelihood Development in Central Asia http://dx.doi.org/10.5716/WP14143.PDF 
187. "Projected Climate Change and Impact on Bioclimatic Conditions in the Central and SouthCentral Asia Region" http://dx.doi.org/10.5716/WP14144.PDF

188. Land Cover Changes, Forest Loss and Degradation in Kutai Barat, Indonesia. http://dx.doi.org/10.5716/WP14145.PDF

189. The Farmer-to-Farmer Extension Approach in Malawi: A Survey of Lead Farmers. http://dx.doi.org/10.5716/WP14152.PDF

190. Evaluating indicators of land degradation and targeting agroforestry interventions in smallholder farming systems in Ethiopia. http://dx.doi.org/10.5716/WP14252.PDF

191. Land health surveillance for identifying land constraints and targeting land management options in smallholder farming systems in Western Cameroon

192. Land health surveillance in four agroecologies in Malawi

193. Cocoa Land Health Surveillance: an evidence-based approach to sustainable management of cocoa landscapes in the Nawa region, South-West Côte d'Ivoire http://dx.doi.org/10.5716/WP14255.PDF

194. Situational analysis report: Xishuangbanna autonomous Dai Prefecture, Yunnan Province, China. http://dx.doi.org/10.5716/WP14255.PDF

195. Farmer-to-farmer extension: a survey of lead farmers in Cameroon. http://dx.doi.org/10.5716/WP15009.PDF

196. From transition fuel to viable energy source Improving sustainability in the sub-Saharan charcoal sector http://dx.doi.org/10.5716/WP15011.PDF

197. Mobilizing Hybrid Knowledge for More Effective Water Governance in the Asian Highlands http://dx.doi.org/10.5716/WP15012.PDF

198. Water Governance in the Asian Highlands http://dx.doi.org/10.5716/WP15013.PDF

199. Assessing the Effectiveness of the Volunteer Farmer Trainer Approach in Dissemination of Livestock Feed Technologies in Kenya vis-à-vis other Information Sources http://dx.doi.org/10.5716/WP15022.PDF

200. The rooted pedon in a dynamic multifunctional landscape: Soil science at the World Agroforestry Centre http://dx.doi.org/10.5716/WP15023.PDF

201. Characterising agro-ecological zones with local knowledge. Case study: Huong Khe district, $\mathrm{Ha}$ Tinh, Viet Nam http://dx.doi.org/10.5716/WP15050.PDF

202. Looking back to look ahead: Insight into the effectiveness and efficiency of selected advisory approaches in the dissemination of agricultural technologies indicative of Conservation Agriculture with Trees in Machakos County, Kenya. http://dx.doi.org/10.5716/WP15065.PDF

203. Pro-poor Biocarbon Projects in Eastern Africa Economic and Institutional Lessons. http://dx.doi.org/10.5716/WP15022.PDF

204. Projected climate change impacts on climatic suitability and geographical distribution of banana and coffee plantations in Nepal. http://dx.doi.org/10.5716/WP15294.PDF

205. Agroforestry and Forestry in Sulawesi series: Smallholders' coffee production and marketing in Indonesia. A case study of two villages in South Sulawesi Province. http://dx.doi.org/10.5716/WP15690.PDF

206. Mobile phone ownership and use of short message service by farmer trainers: a case study of Olkalou and Kaptumo in Kenya http://dx.doi.org/10.5716/WP15691.PDF

207. Associating multivariate climatic descriptors with cereal yields: a case study of Southern Burkina Faso http://dx.doi.org/10.5716/WP15273.PDF

208. Preferences and adoption of livestock feed practices among farmers in dairy management groups in Kenya http://dx.doi.org/10.5716/WP15675.PDF 
209. Scaling up climate-smart agriculture: lessons learned from South Asia and pathways for success http://dx.doi.org/10.5716/WP15720.PDF

210. Agroforestry and Forestry in Sulawesi series: Local perceptions of forest ecosystem services and collaborative formulation of reward mechanisms in South and Southeast Sulawesi http://dx.doi.org/10.5716/WP15721.PDF

211. Potential and challenges in implementing the co-investment of ecosystem services scheme in Buol District, Indonesia. http://dx.doi.org/10.5716/WP15722.PDF 

The World Agroforestry Centre is an autonomous, non-profit research organization whose vision is a rural transformation in the developing world as smallholder households increase their use of trees in agricultural landscapes to improve food security, nutrition, income, health, shelter, social cohesion, energy resources and environmental sustainability. The Centre generates science-based knowledge about the diverse roles that trees play in agricultural landscapes, and uses its research to advance policies and practices, and their implementation that benefit the poor and the environment. It aims to ensure that all this is achieved by enhancing the quality of its science work, increasing operational efficiency, building and maintaining strong partnerships, accelerating the use and impact of its research, and promoting greater cohesion, interdependence and alignment within the organization.

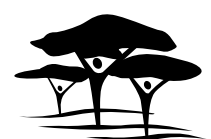

United Nations Avenue, Gigiri • PO Box 30677 • Nairobi, $00100 \cdot$ Kenya Telephone: +254 207224000 or via USA +1 6508336645 Fax: +254207224001 or via USA +1 6508336646

Email: worldagroforestry@cgiar.org•www.worldagroforestry.org

Southeast Asia Regional Program • Sindang Barang • Bogor 16680

PO Box $161 \cdot$ Bogor $16001 \cdot$ Indonesia

Telephone: +62 2518625415 • Fax: +62 2518625416

- Email: icraf-indonesia@cgiar.org

www.worldagroforestry.org/region/southeast-asia

blog.worldagroforestry.org 